\title{
The molecular characterization of porcine egg precursor cells
}

\author{
Te-Sha Tsai ${ }^{1,2}$, Jacqueline Johnson ${ }^{1}$, Yvonne White ${ }^{3}$ and Justin C. St. John ${ }^{1,2}$ \\ ${ }^{1}$ Centre for Genetic Diseases, Hudson Institute of Medical Research, Clayton, Victoria 3168, Australia \\ ${ }^{2}$ Centre for Genetic Diseases, Department of Molecular and Translational Science, Monash University, Clayton, Victoria 3168 , \\ Australia \\ ${ }^{3}$ OvaScience, Inc., Waltham, MA 02451, USA \\ Correspondence to: Justin C. St. John, email: justin.stjohn@hudson.org.au \\ Keywords: egg precursor cells, oogonial stem cells, mitochondrial DNA, mitochondrial supplementation, ageing oocyte \\ Received: May 05, $2017 \quad$ Accepted: June 03, $2017 \quad$ Published: June 28, 2017 \\ Copyright: Tsai et al. This is an open-access article distributed under the terms of the Creative Commons Attribution License 3.0 \\ (CC BY 3.0), which permits unrestricted use, distribution, and reproduction in any medium, provided the original author and source \\ are credited.
}

\section{ABSTRACT}

Female-factor infertility can be caused by poor oocyte quality and depleted ovarian reserves. Egg precursor cells (EPCs), isolated from the ovarian cortex, have the potential to be used to overcome female infertility. We aimed to define the origins of EPCs by analyzing their gene expression profiles and mtDNA content using a minipig model. We characterized FAC-sorted DDX4+-derived porcine EPCs by performing RNA-sequencing and determined that they utilize pathways important for cell cycle and proliferation, which supports the existence of adult mitotically active oogonial cells. Expression of the pluripotent markers Sox 2 and Oct4, and the primitive germ cell markers Blimp1 and Stella were not detected. However, Nanog and Ddx4 were expressed, as were the primitive germ cell markers Fragilis, c-Kit and Tert. Moreover, porcine EPCs expressed self-renewal and proliferation markers including Myc, Esrrb, Id2, KIf4, KIf5, Stat3, Fgfr1, Fgfr2 and II6st. The presence of Zp1, Zp2, Zp3 and Nobox were not detected, indicating that porcine EPCs are not indicative of mature primordial oocytes. We performed mitochondrial DNA Next Generation Sequencing and determined that one mtDNA variant harbored by EPCs was present in oocytes, preimplantation embryos and somatic tissues over three generations in our mini-pig model indicating the potential germline origin of EPCs.

\section{INTRODUCTION}

An increasing number of women are delaying childbirth, and, since oocyte quality declines dramatically after 35 years of age $[1,2]$, more women are requiring assisted reproductive treatments. Male-factor infertility can be overcome by a technique called intracytoplasmic sperm injection (ICSI), which directly injects a sperm into an oocyte, and is one of the most widely used treatments in the fertility clinic [3]. On the other hand, treatment for female-factor infertility is often restricted to in vitro fertilization, since ICSI does not appear to be an effective treatment for poor quality oocytes [4].

The quality of mitochondria and the numbers of copies of its genome, mitochondrial DNA (mtDNA), in oocytes are beginning to be considered, along with other factors, as indicators of oocyte quality, especially in the context of aging [5-11]. The mitochondrial genome is a highly conserved genome, which, at $\sim 16.6 \mathrm{~kb}$ in size, encodes 37 of the genes that are important for functional electron transport chains that generate the vast majority of cellular ATP through oxidative phosphorylation $[12,13]$. Whilst naïve, undifferentiated cells, such as pluripotent stem cells, possess a few hundred copies of mtDNA, terminally differentiated cells with high energy demands, such as neurons and cardiac muscles, possess several thousand copies $[14,15]$.

Low levels of mtDNA have been observed in cohorts of oocytes from couples with female-factor infertility where the oocytes fail to fertilize or arrest during preimplantation development $[7,8,16]$. Moreover, there is evidence to suggest that this is an age-linked phenomenon as mtDNA copy number declines in oocytes with the advancement of age $[17,18]$. In a pig model, we have 
observed mtDNA-deficiency where fertilizable oocytes have $>150,000$ copies of mtDNA [19, 20]. Conversely, metaphase II oocytes that are mtDNA-deficient have $<100,000$ copies of mtDNA, and are less likely to fertilize, or when they do they are more likely to arrest during preimplantation embryo development [19-21]. However, we have recently shown that mtDNA-deficient oocytes can be rescued by supplementation with genetically identical mitochondria, an approach known as mICSI (mitochondrial supplementation as ICSI is preformed) [22]. To this extent, blastocyst quality was significantly improved and global gene expression profiles of the resultant blastocysts closely matched those of mtDNAnormal blastocysts [22], demonstrating the beneficial effects of mitochondrial supplementation to mtDNAdeficient oocytes. Furthermore, mtDNA deficiency is not just restricted to oocytes. It has been reported in premature ovarian failure [23], ovarian insufficiency [8] and diminished ovarian reserve [24].

The number of oocytes that a female possesses, commonly known as her ovarian reserve, is generally considered to be determined at birth [25]. However, recent reports have shown the existence of mitotically active ovarian stem cells in the post-natal ovaries of mice, humans and pigs [26-28]. They are frequently referred to as egg precursor cells (EPCs) and oogonial stem cells, and have been proposed to be a source of cells to repopulate the ovary in the cases of ovarian failure. Furthermore, these cells have been used in a similar approach to mICSI, as a source of mitochondria, that has recently led to the birth of babies [29]. However, the isolation protocol for EPCs remains controversial [30-33]. Although these cells have been shown to generate fertilizable oocytes [27], and have been used to produce live offspring [34, 35], it is highly important to reproduce this protocol and characterize the resultant cells in different mammalian species in order to determine their suitability for use in assisted reproductive technologies.

The exact origins of EPCs still remains to be determined. Germ cell development is initiated from a small population of precursor cells known as primordial germ cells (PGCs), that initially express Fragilis (Ifitm3) followed by the expression of Blimp1 (or Prdm1) and Stella (or Dppa3) [36, 37], which proliferate and migrate to the genital ridge during early embryo development [38]. Specified and migratory PGCs express $D d x 4$ (or Vasa) and Dazl [38-40], as well as the core pluripotency genes Oct4, Sox2 and Nanog [37, 38].

At the beginning of oogenesis, PGC possess $\sim 200$ copies of mtDNA, which then increase to $\sim 2000$ copies, and these are clonally replicated to reach maximal copy number in the maturing oocyte [41-43]. Consequently, any mtDNA sequence variants could be amplified to varying levels in the mature oocyte and persist into adult tissues, which we have observed in our mini-pig model [21], as this is the source of all mtDNA that is inherited in a strictly maternal fashion [44]. Whilst, pathogenic mtDNA sequence variants may lead to poor oocyte quality, many non-pathogenic variants, along with wild-type mtDNA, are likely to be transmitted across generations [21].

In the present work, we have used our established mini-pig model [21] to characterize EPCs to determine the suitability of using these cells for mitochondrial supplementation to improve oocyte quality and for transplantation into the ovary to enhance the ovarian reserve of women with low ovarian reserve, or those having undergone chemotherapy, and require ovarian transplantation. We have used the mini-pig as a model, as its embryology, development, organ systems and physiological and pathophysiological responses are more similar to those of the human than the more commonly used murine models for biomedical and pre-clinical studies $[45,46]$. We used an RNA-sequencing approach to characterize EPCs, and performed in-depth analysis of mtDNA sequence variants using next-generation sequencing to determine the origins of these cells. Our work provides further insight into mammalian ovarian biology, which is important for the understanding of female fertility and ovarian ageing.

\section{RESULTS}

\section{Comparison of the gene expression profiles amongst porcine, human and mouse mitotically active germ cells}

In order to determine whether porcine EPCs expressed germ cell markers, we isolated putative porcine EPCs from ovarian cortex tissue and sorted the cells using an antibody specific to the DDX4 protein. In all, five cohorts of EPCs derived from the same maternal lineage were cultured for one week without passage and then underwent RNA-sequencing. We then compared their gene expression profiles with porcine PGCs, and human and mouse mitotically active germ cells that we had identified from the literature. Here, we determined that Interferon induced transmembrane protein 3 (Ifitm3, also known as Fragilis) is expressed across EPCs, porcine PGCs [47], human mitotically active germ cells [27, 48], putative porcine ovarian stem cells [28], and mouse germ line stem cells $[49,50]$ (Table 1). We also report that EPCs, porcine PGCs and human mitotically active germ cells expressed Telomerase reverse transcriptase (Tert) $[27,47,48]$, which is important for stem cell self-renewal. PR/SET domain 1 (Prdm1, also known as Blimp1) and Developmental pluripotency-associated 3 (Dppa3, also known as Stella) were not expressed by EPCs, although, Dppa 3 was also not expressed by porcine PGCs [47] (Table 1).

We found that Ddx4 (Vasa; DEAD Asp-Glu-AlaAsp box polypeptide 4) was expressed by EPCs, as determined by reverse transcription PCR (RT-PCR) and Sanger sequencing (Supplementary Data 1A and 1B, 
Table 1: Comparison of marker gene expression between EPCs, porcine primordial germ cells, human mitotically active germ cells, porcine ovarian stem cells, and mouse germ line stem cells

\begin{tabular}{|c|c|c|c|c|c|c|c|c|}
\hline $\begin{array}{l}\text { Gene } \\
\text { function }\end{array}$ & $\begin{array}{l}\text { Gene } \\
\text { code }\end{array}$ & Gene name & $\begin{array}{l}\text { Porcine } \\
\text { EPC }\end{array}$ & $\begin{array}{l}\text { Porcine } \\
\text { embryonic } \\
\text { germ cell/ } \\
\text { primordial } \\
\text { germ cell } \\
\text { (Petkov } \\
\text { 2011) [47] }\end{array}$ & $\begin{array}{l}\text { Porcine ovarian } \\
\text { putative stem } \\
\text { cells (Bui 2014) } \\
{[28]}\end{array}$ & $\begin{array}{l}\text { Human } \\
\text { mitotically } \\
\text { active germ } \\
\text { cells) (White } \\
2012 \text {, Woods } \\
\text { 2013) }[27,48]\end{array}$ & $\begin{array}{l}\text { Mouse female } \\
\text { germ line stem } \\
\text { cell (Xie 2014) } \\
{[50]}\end{array}$ & $\begin{array}{l}\text { Cultured mouse } \\
\text { mitotically } \\
\text { active germ cells } \\
\text { (Imudia 2013) } \\
\text { [49] }\end{array}$ \\
\hline $\begin{array}{l}\text { Primitive } \\
\text { germ cell } \\
\text { marker }\end{array}$ & $\begin{array}{l}\text { Prdm1/ } \\
\text { Blimp1 }\end{array}$ & $\begin{array}{l}\text { PR/SET domain } \\
1\end{array}$ & no & yes & yes & yes & yes & yes \\
\hline \multirow{7}{*}{$\begin{array}{l}\text { Commonly } \\
\text { used germ } \\
\text { line marker }\end{array}$} & $\begin{array}{l}\text { Dppa3/ } \\
\text { Stella }\end{array}$ & $\begin{array}{l}\text { Developmental } \\
\text { pluripotency- } \\
\text { associated } 3\end{array}$ & no & no & not determined & yes & yes & yes \\
\hline & $\begin{array}{l}\text { Ifitm3/ } \\
\text { Fragilis }\end{array}$ & $\begin{array}{l}\text { Interferon } \\
\text { induced } \\
\text { transmembrane } \\
\text { protein } 3\end{array}$ & yes & yes & yes & yes & yes & yes \\
\hline & Tert & $\begin{array}{l}\text { Telomerase } \\
\text { reverse } \\
\text { transcriptase }\end{array}$ & yes & yes & not determined & yes & not determined & not determined \\
\hline & Dazl & DAZ Homolog & no & $\begin{array}{l}\text { not } \\
\text { determined }\end{array}$ & yes & yes & yes & yes \\
\hline & $\begin{array}{l}\text { Ddx } 4 / \\
\text { Vasa }\end{array}$ & $\begin{array}{l}\text { DEAD (Asp-Glu- } \\
\text { Ala-Asp) box } \\
\text { polypeptide } 4\end{array}$ & yes* & $\begin{array}{l}\text { not } \\
\text { determined }\end{array}$ & yes & yes & not determined & yes \\
\hline & Kit/c-kit & $\begin{array}{l}\text { KIT proto- } \\
\text { oncogene } \\
\text { receptor tyrosine } \\
\text { kinase }\end{array}$ & yes & yes & yes & not determined & no & not determined \\
\hline & $\begin{array}{l}\text { Adad1/ } \\
\text { Tenr }\end{array}$ & $\begin{array}{l}\text { Adenosine } \\
\text { deaminase } \\
\text { domain } \\
\text { containing } 1\end{array}$ & yes & yes & not determined & not determined & not determined & not determined \\
\hline \multirow{3}{*}{$\begin{array}{l}\text { Meiosis } \\
\text { marker }\end{array}$} & Sycp2 & $\begin{array}{l}\text { Synaptonemal } \\
\text { complex protein } \\
2\end{array}$ & yes & yes & not determined & not determined & not determined & not determined \\
\hline & Stra8 & $\begin{array}{l}\text { Stimulated By } \\
\text { Retinoic Acid } 8\end{array}$ & no & $\begin{array}{l}\text { not } \\
\text { determined }\end{array}$ & not determined & not determined & not determined & yes \\
\hline & Meioc & $\begin{array}{l}\text { Meiosis Specific } \\
\text { With Coiled-Coil } \\
\text { Domain }\end{array}$ & no & $\begin{array}{l}\text { not } \\
\text { determined }\end{array}$ & not determined & not determined & not determined & not determined \\
\hline $\begin{array}{l}\text { Oocyte/ } \\
\text { follicle } \\
\text { marker }\end{array}$ & Fig $\alpha$ & $\begin{array}{l}\text { Folliculogenesis } \\
\text { Specific BHLH } \\
\text { Transcription } \\
\text { Factor }\end{array}$ & no & $\begin{array}{l}\text { not } \\
\text { determined }\end{array}$ & not determined & not determined & yes & not determined \\
\hline
\end{tabular}

(Continued) 


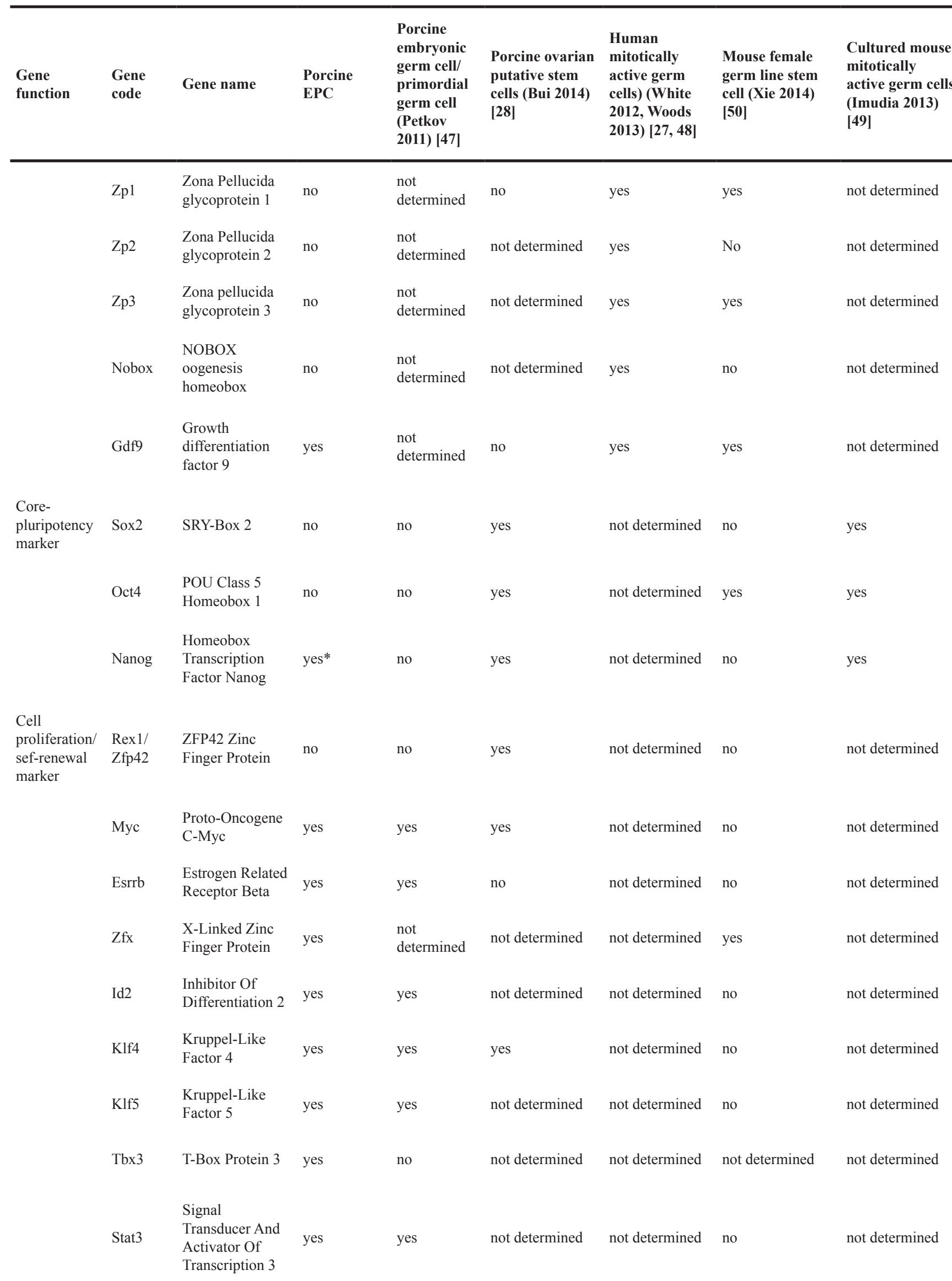

(Continued) 


\begin{tabular}{|c|c|c|c|c|c|c|c|c|}
\hline $\begin{array}{l}\text { Gene } \\
\text { function }\end{array}$ & $\begin{array}{l}\text { Gene } \\
\text { code }\end{array}$ & Gene name & $\begin{array}{l}\text { Porcine } \\
\text { EPC }\end{array}$ & $\begin{array}{l}\text { Porcine } \\
\text { embryonic } \\
\text { germ cell/ } \\
\text { primordial } \\
\text { germ cell } \\
\text { (Petkov } \\
\text { 2011) [47] }\end{array}$ & $\begin{array}{l}\text { Porcine ovarian } \\
\text { putative stem } \\
\text { cells (Bui 2014) } \\
{[28]}\end{array}$ & $\begin{array}{l}\text { Human } \\
\text { mitotically } \\
\text { active germ } \\
\text { cells) (White } \\
\text { 2012, Woods } \\
2013 \text { ) [27, 48] }\end{array}$ & $\begin{array}{l}\text { Mouse female } \\
\text { germ line stem } \\
\text { cell (Xie 2014) } \\
\text { [50] }\end{array}$ & $\begin{array}{l}\text { Cultured mouse } \\
\text { mitotically } \\
\text { active germ cells } \\
\text { (Imudia 2013) } \\
\text { [49] }\end{array}$ \\
\hline & Fgfr1 & $\begin{array}{l}\text { Fibroblast } \\
\text { Growth Factor } \\
\text { Receptor } 1\end{array}$ & yes & yes & not determined & not determined & no & not determined \\
\hline & Fgfr2 & $\begin{array}{l}\text { Fibroblast } \\
\text { Growth Factor } \\
\text { Receptor } 2\end{array}$ & yes & yes & not determined & not determined & no & not determined \\
\hline & Lifr/Il6st & $\begin{array}{l}\text { Leukemia } \\
\text { Inhibitory Factor } \\
\text { Receptor }\end{array}$ & yes & yes & not determined & not determined & no & not determined \\
\hline & Pparg & $\begin{array}{l}\text { Peroxisome } \\
\text { Proliferator } \\
\text { Activated } \\
\text { Receptor Gamma }\end{array}$ & yes & $\begin{array}{l}\text { not } \\
\text { determined }\end{array}$ & not determined & not determined & no & not determined \\
\hline \multirow[t]{5}{*}{$\begin{array}{l}\text { Cell cycle } \\
\text { marker }\end{array}$} & Cdk1 & $\begin{array}{l}\text { Cyclin-dependent } \\
\text { kinase } 1\end{array}$ & yes & $\begin{array}{l}\text { not } \\
\text { determined }\end{array}$ & not determined & not determined & yes & not determined \\
\hline & $\mathrm{Cdk} 2$ & $\begin{array}{l}\text { Cyclin-dependent } \\
\text { kinase } 2\end{array}$ & yes & $\begin{array}{l}\text { not } \\
\text { determined }\end{array}$ & not determined & not determined & yes & not determined \\
\hline & Rpa1 & $\begin{array}{l}\text { Replication } \\
\text { protein A1 }\end{array}$ & yes & $\begin{array}{l}\text { not } \\
\text { determined }\end{array}$ & not determined & not determined & yes & not determined \\
\hline & Rabgap1 & $\begin{array}{l}\text { RAB GTPase } \\
\text { activating protein } \\
1\end{array}$ & yes & $\begin{array}{l}\text { not } \\
\text { determined }\end{array}$ & not determined & not determined & yes & not determined \\
\hline & App & $\begin{array}{l}\text { Amyloid beta } \\
\text { precursor protein }\end{array}$ & yes & $\begin{array}{l}\text { not } \\
\text { determined }\end{array}$ & not determined & not determined & yes & not determined \\
\hline
\end{tabular}

Footnote: * indicates that gene expression was not detected by RNA-sequencing after data normalization, but was detected in RT-PCR.

respectively). Other commonly used germ line markers including KIT proto-oncogene receptor tyrosine kinase (Kit or $c$-kit), Adenosine deaminase domain containing 1 (Adad1 or Tenr) and Synaptonemal complex protein 2 (Sycp2), were expressed by both EPCs and porcine PGCs [47], which further demonstrates the similarity between these two populations (Table 1). To assess whether meiosis is initiated in EPCs, we found that Stimulated By Retinoic 8 (Stra 8 ) is not expressed by EPCs, but is expressed in mouse mitotically active germ cells [49] (Table 1). Likewise, the meiotic marker, Meiosis Specific With Coiled-Coil Domain (Meioc) is not expressed by EPCs (Table 1). Both populations did not express oocyte markers NOBOX oogenesis homeobox
(Nobox), Zona pellucida glycoproteins 1 to 3 (Zpl to 3 ), or Folliculogenesis Specific BHLH Transcription Factor (Fig $\alpha$ ), and only EPCs expressed Growth differentiation factor 9 (Gdf9) [47] (Table 1). Both EPCs and porcine PGCs did not express pluripotency markers SRY-Box 2 (Sox2) or POU Class 5 Homeobox 1 (Oct4), which differs to putative pig ovarian stem cells and cultured mouse mitotically active germ cells (Table 1) [28, 49]. However, when we performed RT-PCR, we detected expression of the Homeobox Transcription Factor Nanog (Nanog) in EPCs (Table 1 and Supplementary Data 1A).

To determine the cell proliferation and self-renewal potential of EPCs, we assessed markers such as ProtoOncogene C-Myc (Myc), Estrogen Related Receptor Beta 
(Esrrb), Inhibitor Of Differentiation 2 (Id2), KruppelLike Factor 4 (Klf4), Kruppel-Like Factor 5 (Klf5), Signal Transducer And Activator Of Transcription 3 (Stat3), Fibroblast Growth Factor Receptor 1 ( $F g f r 1)$, Fibroblast Growth Factor Receptor 2 ( $F g f r 2)$, and Leukemia Inhibitory Factor Receptor (Lifr), and found that they were commonly expressed by EPCs and porcine PGCs [47] (Table 1). Moreover, EPCs expressed cell cycle markers Cyclin-dependent kinase 1 (Cdkl), Cyclin-dependent kinase 2 (Cdk2), Replication protein A1 (Rpa1), RAB GTPase activating protein 1 (Rabgap1) and Amyloid beta precursor protein $(A p p)$ (Table 1), which suggests that EPCs are mitotically active.

\section{Gene ontology using the PANTHER classification system}

The entire list of normalized RNA-sequencing data, which consisted of 13806 genes, was then analyzed using the "Gene List Analysis" tool, from the Gene Ontology Consortium database. Here, we report that the top five biological functions for EPCs were cellular process (GO:0009987; 3891/13175 genes), metabolic process (GO:0008152; 3640/13175 genes), localization (GO:0051179; 1066/13175 genes), cellular component organization or biogenesis (GO:0071840; 923/13175 genes), and response to stimulus (GO:0050896; 865/13175) (Supplementary Data 2A and 2B, respectively).

Within the cellular process category, the functions of those genes were further determined (Figure 1). The top five cellular functions (Figure 1A) and the number of genes involved (Figure 1B) were cell communication (GO:0007154; 1101/1962 genes), cell cycle (GO:0007049; 494/1962 genes), cellular component movement (GO:0006928; 192/1962 genes), chromosome segregation (GO:0007059; 68/1962 genes), and cell proliferation (GO:0008283; 52/1962 genes). Together, these data demonstrate that EPCs have the propensity to be mitotically active and proliferate.

\section{Top canonical pathways and cellular functions utilized by EPCs}

To further elucidate the gene expression profiles, we used another bioinformatics analytical software tool, Ingenuity Pathway Analysis (IPA). We determined the major canonical pathways utilized by EPCs using the 'Core analysis' tool. The top five canonical pathways were EIF2 signaling, which plays a role in protein synthesis $\left(\mathrm{P}=7.30 \times 10^{-45}\right)$; regulation of eIF4 and p70S6K signaling, which is critical for translational regulation $\left(\mathrm{P}=1.43 \times 10^{-34}\right)$; mTOR signaling, which is involved in cell survival and proliferation $\left(\mathrm{P}=9.30 \times 10^{-29}\right)$; the protein ubiquitination pathway, which plays a role in the degradation of short lived regulatory proteins $\left(\mathrm{P}=6.79 \times 10^{-27}\right)$; and the $\mathrm{PI} 3 \mathrm{~K} /$
AKT signaling pathway, which plays a central role in signal transduction pathways of cytokines, growth factors and other extracellular matrix proteins $\left(\mathrm{P}=4.80 \times 10^{-20}\right)$ (Supplementary Data 3 and 4). These pathways are important since protein synthesis is essential for germline stem cells to continue proliferation, to differentiate or to enter apoptosis [51].

The IPA 'Core Analysis' tool also determined that the top molecular and cellular functions of EPCs are: cell death and survival (from 1651 genes; $\mathrm{P}=1.59 \times 10^{-09}$ to $4.78 \times 10^{-96}$ ), cellular growth and proliferation (from 1814 genes; $\mathrm{P}=5.50 \times 10^{-10}$ to $3.42 \times 10^{-84}$ ), gene expression (from 1136 genes; $\mathrm{P}=1.38 \times 10^{-11}$ to $3.75 \times 10^{-70}$ ), protein synthesis (from 526 genes; $2.03 \times 10^{-13}$ to $1.68 \times 10^{-64}$ ) and RNA posttranscriptional modification (from 222 genes; $\mathrm{P}=4.83 \times 10^{-16}$ to $1.49 \times 10^{-62}$ ). Moreover, the top predicted developmental functions are: organismal survival (from 1130 genes; $\mathrm{P}=1.49 \times 10^{-14}$ to $1.42 \times 10^{-74}$ ), embryonic development (from 837 genes; $\mathrm{P}=8.04 \times 10^{-10}$ to $1.60 \times 10^{-34}$ ), organismal development (from 1293 genes; $\mathrm{P}=1.29 \times 10^{-9}$ to $1.60 \times 10^{-}$ ${ }^{34}$ ), tissue morphology (from 611 genes; $\mathrm{P}=6.84 \times 10^{-10}$ to $1.60 \times 10^{-34}$ ) and cardiovascular system development and function (from 650 genes; $1.73 \times 10^{-9}$ to $2.09 \times 10^{-}$ ${ }^{28}$ ) (Supplementary Data 4). These predicted functions indicate that EPCs have the transcripts to support early embryo development.

\section{Top gene regulation networks utilized by EPCs}

The top four gene networks of that were identified by IPA to be significantly utilized (network score $\geq 30$ ) were those involved in: connective tissue development, cancer, cell death and survival, and gene expression (Table 2). An important caveat for interpreting IPA network analysis is that its results mainly focus on diseases and functions. However, pathways involved in cell death and survival and cancer are also often utilized by, for example, stem cells [52]. Overall, the top eleven networks (network score $\geq 28$ ), showed that EPCs utilized pathways that are important for cell morphology, cellular assembly and organization, cell to cell signaling, cell growth and proliferation, and cellular development (Table 2). These results are consistent with the top biological functions determined by PANTHER and the major canonical pathways determined by IPA.

\section{Top upstream regulators that determine EPC gene expression}

Upstream regulators are master molecules that target and regulate gene expression in EPCs. We have identified these upstream molecules to provide further support to our biological function analysis. Here, we identified 477 upstream regulators that activate, and 246 that inhibit EPC gene expression (Supplementary Data 5). The activating 
upstream regulators, as determined by IPA, included 87 transcription regulators, 29 growth factors, 7 nuclear receptors and 24 cytokines. All regulators identified have a $\mathrm{z}$-score of $>2$ or $<2$ and were ranked from the lowest to highest P-value (all <0.05) (Supplementary Data 5).

The top ten activating transcription regulators were $\mathrm{v}$-myc avian myelocytomatosis viral oncogene homolog $(M y c)$, tumor protein p53 (Tp53), hepatocyte nuclear factor 4 alpha (Hnf4a), v-myc avian myelocytomatosis viral oncogene neuroblastoma derived homolog $(M y c n)$,
X-box binding protein $1(X b p 1)$, nuclear factor, erythroid 2 like 2 ( $N f e 2 l 2$ ), hypoxia inducible factor 1 alpha subunit (Hifla), huntingtin (Htt), E2F transcription factor 1 (E2fl), and Fos proto-oncogene, AP-1 transcription factor subunit (Fos) (Table 3). These genes are involved in the biological functions of cell proliferation, cell cycle regulation, cellular response to stress and nutrient, and maintenance of cell homeostasis (Table 3 ).

The top seven positive nuclear-receptor regulators were estrogen receptor 1 ( $E s r l)$, progesterone receptor

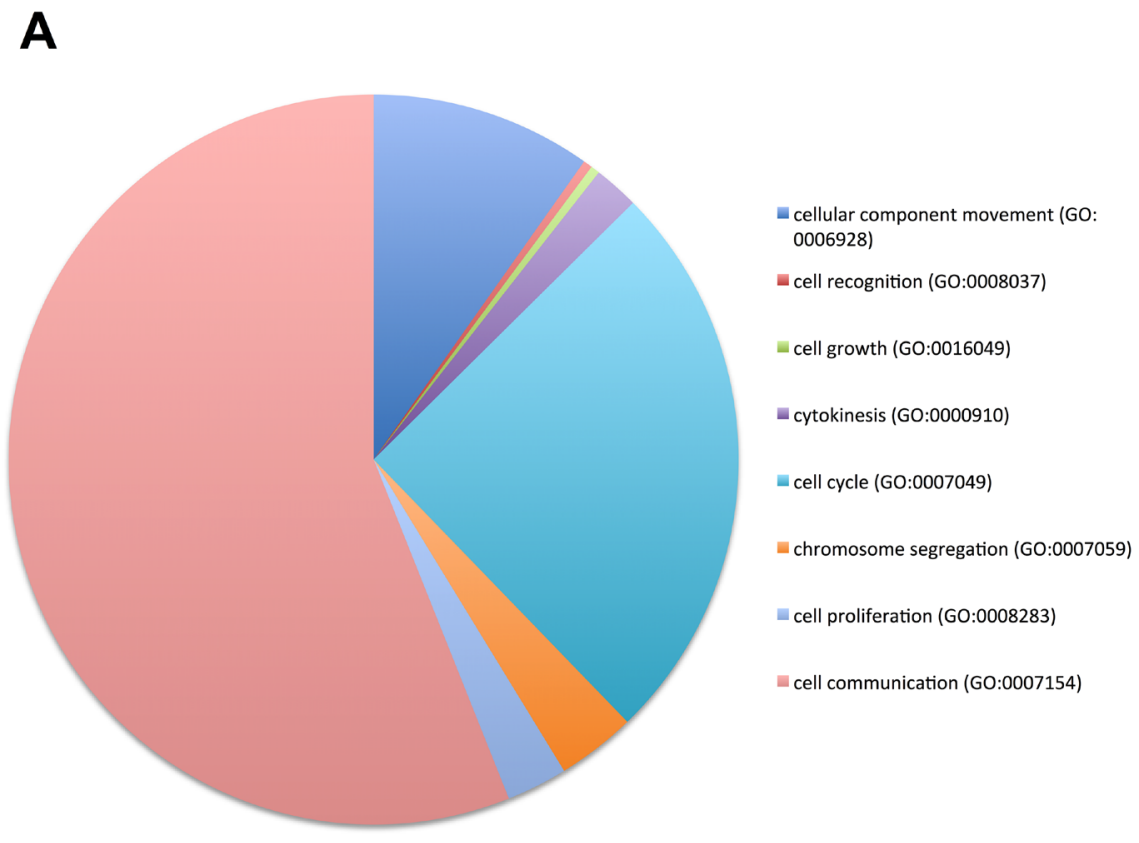

B

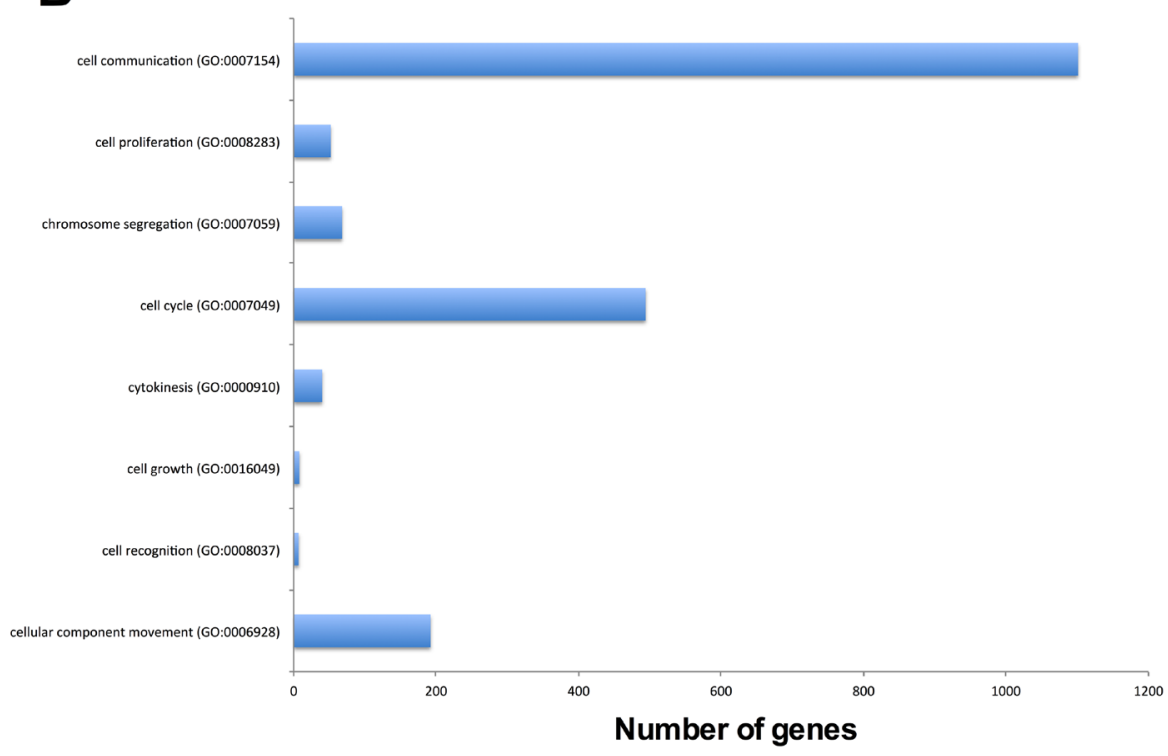

Figure 1: Top cellular functions of EPCs, as determined by the PANTHER classification system from the Gene Ontology Consortium database (A), and the number of genes involved (B). 
Table 2: Top gene networks utilized by EPCs as determined by Ingenuity Pathway Analysis

\begin{tabular}{|c|c|c|c|}
\hline Top diseases and functions & Molecules in network & IPA score & Focus molecules \\
\hline $\begin{array}{l}\text { Connective Tissue } \\
\text { Development and Function, } \\
\text { Developmental Disorder, } \\
\text { Hereditary Disorder }\end{array}$ & $\begin{array}{l}\text { ADRBK1, ARGLU1, } \\
\text { C1D, CDKN2AIPNL, } \\
\text { DCAF10, ENOPH1, ESCO1, } \\
\text { ETFA, ETFDH, EXOSC7, } \\
\text { EXOSC9, FAM133B, } \\
\text { FOCAD, HEXA, HEXB, } \\
\text { HPS5, KIAA2013, MAK16, } \\
\text { MRPS35, NCS1, NNT, } \\
\text { PAPD7, PAPSS1, PAPSS2, } \\
\text { RMND5A, SLAIN2, SMC5, } \\
\text { SMC6, SMYD5, SS18L2, } \\
\text { TMEM132A, TSNAX, } \\
\text { TUFT1, WAC, YPEL5 }\end{array}$ & 30 & 35 \\
\hline $\begin{array}{l}\text { Cancer, Hematological } \\
\text { Disease, Immunological } \\
\text { Disease }\end{array}$ & $\begin{array}{l}\text { ABL1, ARL5A, ATIC, } \\
\text { BOD1L1, CBX3, CHD4, } \\
\text { CNBP, DDX47, DEGS1, } \\
\text { DHX15, DPY19L1, EIF5B, } \\
\text { FJX1, FUBP1, GART, } \\
\text { HDGF, KDM3B, KDM5B, } \\
\text { KPNA2, LMNB2, MTF2, } \\
\text { NCBP1, PAICS, PLS3, } \\
\text { PRPS1, PSIP1, RBBP4, } \\
\text { RCOR1, RECQL, SETX, } \\
\text { SLC16A1, STK38, SUB1, } \\
\text { ZDHHC16, ZNF217 }\end{array}$ & 30 & 35 \\
\hline $\begin{array}{l}\text { Cell Death and Survival, } \\
\text { Infectious Diseases, Gene } \\
\text { Expression }\end{array}$ & $\begin{array}{l}\text { AMBRA1, ANP32B, } \\
\text { ATF7IP, BUB1, CPEB2, } \\
\text { EEF2, ERCC3, GANAB, } \\
\text { HSDL2, HSP90AA1, } \\
\text { HUWE1, KCTD2, KDM4B, } \\
\text { KIF1B, LRRC42, MACF1, } \\
\text { MAST2, MXRA7, NANS, } \\
\text { NUF2, PCBP1, PCMT1, } \\
\text { PPIG, PSMA1, PSMA3, } \\
\text { PSMC1, PSMC3, PSMC5, } \\
\text { PSMD2, RAD23B, } \\
\text { RALBP1, RNASEH2C, } \\
\text { SNTB2, TFE3, TNIK }\end{array}$ & 30 & 35 \\
\hline $\begin{array}{l}\text { Gene Expression, } \\
\text { Connective Tissue Disorders, } \\
\text { Developmental Disorder }\end{array}$ & $\begin{array}{l}\text { ACER3, ANO6, CCDC25, } \\
\text { CDR2L, CHSY1, COQ10B, } \\
\text { DCUN1D4, EFCAB14, } \\
\text { ELAVL1, ERMP1, } \\
\text { FAM105A, HECA, IER3IP1, } \\
\text { ISOC1, MEX3D, MGAT2, } \\
\text { PCNP, PDZD8, PEX19, } \\
\text { PITHD1, RAP2C, S100PBP, } \\
\text { SELT, SLC10A3, SLC18B1, } \\
\text { SMIM7, SPPL3, TM7SF3, } \\
\text { TMCO1, TMEM123, } \\
\text { TMEM167B, TMEM41B, } \\
\text { TMX1, ZNF521, ZNF664 }\end{array}$ & 30 & 35 \\
\hline
\end{tabular}

(Continued) 


\begin{tabular}{|c|c|c|c|}
\hline Top diseases and functions & Molecules in network & IPA score & Focus molecules \\
\hline $\begin{array}{l}\text { Cell Morphology, Cellular } \\
\text { Assembly and Organization, } \\
\text { Cellular Function and } \\
\text { Maintenance }\end{array}$ & $\begin{array}{l}\text { 60S ribosomal subunit, } \\
\text { ABCF1, BMS1, CBY1, } \\
\text { CEP164, DDX24, DNTTIP2, } \\
\text { DZIP1, FRYL, GALK1, } \\
\text { GNL2, GRK5, KIAA0930, } \\
\text { MRTO4, MYBBP1A, NIFK, } \\
\text { NLE1, NMD3, NSA2, } \\
\text { OTUD4, PAK1IP1, PEF1, } \\
\text { PTCD3, PUM3, RPF1, } \\
\text { RPL8, RPL14, RPL26L1, } \\
\text { RPL7L1, RRP8, RSL24D1, } \\
\text { STAU2, USP36, UTP18, } \\
\text { WDR3 }\end{array}$ & 28 & 34 \\
\hline $\begin{array}{l}\text { Cancer, Cell Death and } \\
\text { Survival, Organismal Injury } \\
\text { and Abnormalities }\end{array}$ & $\begin{array}{l}\text { EBNA1BP2, GNRH, } \\
\text { GRSF1, HAUS2, KRR1, } \\
\text { MRPL3, MRPL24, } \\
\text { MRPL38, MRPL40, } \\
\text { MRPL46, MRPS6, MRPS7, } \\
\text { MRPS9, MRPS10, MRPS22, } \\
\text { MRPS26, MRPS27, } \\
\text { MRPS34, NEMF, PREP, } \\
\text { RANBP6, RPL6, RPL13, } \\
\text { RPL15, RPL17, RPL26, } \\
\text { RPL27, RPL34, RPL38, } \\
\text { RPL27A, RPS8, SMIM20, } \\
\text { SRSF9, SUCO, TRA2A }\end{array}$ & 28 & 34 \\
\hline $\begin{array}{l}\text { Cellular Assembly and } \\
\text { Organization, Cell-To-Cell } \\
\text { Signaling and Interaction, } \\
\text { Reproductive System } \\
\text { Development and Function }\end{array}$ & $\begin{array}{l}\text { ACTR1B, AHI1, CCT2, } \\
\text { CCT3, CCT4, CCT5, } \\
\text { CCT7, CCT8, CCT6A, } \\
\text { CIPC, DCAF7, DENND4C, } \\
\text { DOCK5, DSP, ECD, HSF2, } \\
\text { MAPK9, NMT1, PDCD10, } \\
\text { Ppp2c, PPP2CB, PPP2R1A, } \\
\text { PPP2R1B, PPP2R2A, } \\
\text { PPP2R5C, RABGEF1, } \\
\text { SIRT2, STK24, STK25, } \\
\text { STRN, SUN2, TCP1, } \\
\text { TRMT112, TXNDC9, } \\
\text { UNC45A }\end{array}$ & 28 & 34 \\
\hline $\begin{array}{l}\text { Cardiovascular Disease, } \\
\text { Connective Tissue Disorders, } \\
\text { Developmental Disorder }\end{array}$ & $\begin{array}{l}\text { ANKIB1, ATG2B, } \\
\text { ATP8B2, CCDC50, CDIP1, } \\
\text { CTTNBP2NL, DCHS1, } \\
\text { DENR, DHRS7, FAR1, } \\
\text { FARSA, GRAMD1A, } \\
\text { HECTD1, ITM2B, Lamin, } \\
\text { LRRC57, MFAP3, MRPL49, } \\
\text { NUP155, NUTF2, OTUD7B, } \\
\text { R3HDM4, RNF19B, RYK, } \\
\text { SBF2, STRN4, TALDO1, } \\
\text { TMEM59, TMEM30A, } \\
\text { TMEM59L, TXNL1, UBC, } \\
\text { ZDHHC20, ZFAND3, } \\
\text { ZRANB1 }\end{array}$ & 28 & 34 \\
\hline
\end{tabular}




\begin{tabular}{|c|c|c|c|}
\hline Top diseases and functions & Molecules in network & IPA score & Focus molecules \\
\hline $\begin{array}{l}\text { Cell Signaling, Gene } \\
\text { Expression, Cellular } \\
\text { Function and Maintenance }\end{array}$ & $\begin{array}{l}\text { ACADVL, CAD, CBL, } \\
\text { CDK9, CHD1, CNN1, } \\
\text { DCTN3, DECR1, FLOT1, } \\
\text { FOXP4, HMMR, KLHL12, } \\
\text { LRPPRC, MED4, MED8, } \\
\text { MED12, MED16, MED17, } \\
\text { MED25, MED28, mediator, } \\
\text { MMS19, NIPBL, OSTF1, } \\
\text { POLR2A, QKI, RPLP2, } \\
\text { RUVBL2, SART3, } \\
\text { SKIV2L2, THRAP3, } \\
\text { TRRAP, TXLNA, TXLNG, } \\
\text { ZW10 }\end{array}$ & 28 & 34 \\
\hline $\begin{array}{l}\text { Small Molecule } \\
\text { Biochemistry, Post- } \\
\text { Translational Modification, } \\
\text { Lipid Metabolism }\end{array}$ & $\begin{array}{l}\text { APPBP2, BNIP3, CACFD1, } \\
\text { Ces, COMT, CREB3, } \\
\text { CYP51A1, DAD1, } \\
\text { EBP, ENC1, FAM213A, } \\
\text { FAM3A, FIS1, HSD3B1, } \\
\text { IFRD1, IMPDH1, MFSD7, } \\
\text { MFSD11, MSMO1, } \\
\text { NFE2L2, NUCB2, OAF, } \\
\text { OAT, ORMDL1, SLC39A13, } \\
\text { SLC41A2, SPTSSA, } \\
\text { ST3GAL4, TBC1D15, } \\
\text { TMEM115, TMEM230, } \\
\text { TPI1, UGGT2, UNC50, } \\
\text { VKORC1 }\end{array}$ & 28 & 34 \\
\hline $\begin{array}{l}\text { Cell Death and Survival, } \\
\text { Cellular Development, } \\
\text { Cellular Growth and } \\
\text { Proliferation }\end{array}$ & $\begin{array}{l}\text { ABRACL, ANXA2, BTG3, } \\
\text { CCPG1, CDC37, CEP290, } \\
\text { CTNND1, CUL2, DCTN1, } \\
\text { EWSR1, Fgf, FGF11, FUS, } \\
\text { GLS, HLTF, MAOB, MET, } \\
\text { NAP1L3, NRP1, PKM, } \\
\text { PRPF19, RARA, RBPJ, } \\
\text { RCC1, SDC1, SMARCA4, } \\
\text { SNW1, SSB, SUZ12, } \\
\text { TFIP11, TNC, UPF1, VCP, } \\
\text { WRNIP1, YBX1 }\end{array}$ & 28 & 34 \\
\hline
\end{tabular}

$(P g r)$, peroxisome proliferator activated receptor gamma (Pparg), peroxisome proliferator activated receptor alpha (Ppara), androgen receptor $(A r)$, estrogen related receptor alpha (Esrra), and estrogen related receptor gamma (Esrrg). These ligand-regulated transcription factors play key roles in regulating cell growth and proliferation, lipid and glucose metabolism and follicular growth (Table 3).

The top ten growth factors were transforming growth factor beta $1(T g f b 1)$, hepatocyte growth factor $(H g f)$, angiopoietin 2 (Angpt2), vascular endothelial growth factor A (Vegfa), epidermal growth factor $(E g f)$, transforming growth factor beta 3 (Tgfb3), angiotensinogen $(A g t)$, insulin like growth factor 1
(Igf1), fibroblast growth factor $2(F g f 2)$, and KIT ligand (Kitlg). These growth factors are important for germ cell development, cell proliferation, cell metabolism and cell migration (Table 3).

Upstream regulatory molecules that inhibit EPC gene expression included 27 transcription regulators, 1 growth factor, 42 mature microRNAs and 27 microRNAs (Supplementary Data 5). The top ten inhibiting transcription regulators were nuclear protein 1 (Nupr 1 ), promyelocytic leukemia $(\mathrm{Pml})$, cyclin dependent kinase inhibitor 2A (Cdkn2a), Kruppel like factor 3 (Klf3), SMAD family member 7 ( $\operatorname{Smad} 7)$, lysine demethylase 5A $(K d m 5 a)$, lysine demethylase 5B $(K d m 5 b)$, SAM pointed 
Table 3: Upstream regulators that positively regulate EPC gene expression as determined by Ingenuity Pathway Analysis

\begin{tabular}{|c|c|c|c|c|c|}
\hline Molecule type & Upstream regulator & $\begin{array}{l}\text { Biological } \\
\text { function }\end{array}$ & $\begin{array}{c}\begin{array}{c}\text { No. of target } \\
\text { genes }\end{array} \\
\end{array}$ & P-value & Z-score \\
\hline \multirow[t]{10}{*}{$\begin{array}{l}\text { Transcription } \\
\text { Regulator }\end{array}$} & MYC & $\begin{array}{l}\text { Cell } \\
\text { proliferation, } \\
\text { cell cycle } \\
\text { regulation }\end{array}$ & 457 & $2.32 \mathrm{E}-83$ & 8.884 \\
\hline & TP53 & $\begin{array}{l}\text { Cell cycle } \\
\text { regulation }\end{array}$ & 563 & $2.23 \mathrm{E}-82$ & 4.559 \\
\hline & HNF4A & $\begin{array}{l}\text { Glucose } \\
\text { homeostasis, } \\
\text { lipid } \\
\text { homeostasis }\end{array}$ & 728 & $1.51 \mathrm{E}-81$ & 2.167 \\
\hline & MYCN & $\begin{array}{l}\text { Cell } \\
\text { proliferation }\end{array}$ & 165 & $2.67 \mathrm{E}-60$ & 2.925 \\
\hline & XBP1 & $\begin{array}{l}\text { Cellular } \\
\text { response to } \\
\text { nutrient, cell } \\
\text { growth }\end{array}$ & 124 & $5.36 \mathrm{E}-40$ & 9.837 \\
\hline & NFE2L2 & $\begin{array}{l}\text { Cellular } \\
\text { response to } \\
\text { stress }\end{array}$ & 166 & $1.56 \mathrm{E}-26$ & 11.009 \\
\hline & HIF1A & $\begin{array}{l}\text { Cellular } \\
\text { response to } \\
\text { hypoxia }\end{array}$ & 147 & $3.55 \mathrm{E}-20$ & 8.085 \\
\hline & HTT & $\begin{array}{l}\text { Regulation of } \\
\text { mitochondrial } \\
\text { function }\end{array}$ & 232 & $6.71 \mathrm{E}-20$ & 4.924 \\
\hline & $\mathrm{E} 2 \mathrm{~F} 1$ & $\begin{array}{l}\text { Cell cycle } \\
\text { regulation }\end{array}$ & 168 & $9.48 \mathrm{E}-20$ & 4.241 \\
\hline & FOS & $\begin{array}{l}\text { Cellular } \\
\text { response to } \\
\text { stimulus }\end{array}$ & 187 & $1.12 \mathrm{E}-18$ & 2.507 \\
\hline \multirow[t]{4}{*}{ Nuclear Receptor } & ESR1 & $\begin{array}{l}\text { Ovarian follicle } \\
\text { growth }\end{array}$ & 438 & $9.49 \mathrm{E}-41$ & 5.358 \\
\hline & PGR & $\begin{array}{l}\text { Cellular } \\
\text { response to } \\
\text { gonadotropin }\end{array}$ & 110 & $1.53 \mathrm{E}-16$ & 6.862 \\
\hline & PPARG & $\begin{array}{l}\text { Lipid } \\
\text { metabolism, } \\
\text { glucose } \\
\text { homeostasis }\end{array}$ & 139 & $9.64 \mathrm{E}-10$ & 3.756 \\
\hline & PPARA & $\begin{array}{l}\text { Glucose } \\
\text { metabolism, } \\
\text { fatty acid } \\
\text { metabolism }\end{array}$ & 116 & $9.18 \mathrm{E}-06$ & 4.608 \\
\hline
\end{tabular}

(Continued) 


\begin{tabular}{|c|c|c|c|c|c|}
\hline Molecule type & Upstream regulator & $\begin{array}{l}\text { Biological } \\
\text { function }\end{array}$ & $\begin{array}{l}\text { No. of target } \\
\text { genes }\end{array}$ & P-value & Z-score \\
\hline & $\mathrm{AR}$ & $\begin{array}{l}\text { Cell growth and } \\
\text { proliferation }\end{array}$ & 116 & $2.05 \mathrm{E}-05$ & 6.679 \\
\hline & ESRRA & $\begin{array}{l}\text { Cell } \\
\text { proliferation }\end{array}$ & 53 & $1.86 \mathrm{E}-04$ & 5.735 \\
\hline & ESRRG & $\begin{array}{l}\text { Cell } \\
\text { proliferation }\end{array}$ & 14 & $7.26 \mathrm{E}-03$ & 3.121 \\
\hline \multirow[t]{10}{*}{ Growth Factor } & TGFB1 & $\begin{array}{l}\text { Cell growth and } \\
\text { proliferation, } \\
\text { migration }\end{array}$ & 550 & $1.54 \mathrm{E}-49$ & 10.924 \\
\hline & HGF & $\begin{array}{l}\text { Cell } \\
\text { proliferation } \\
\text { migration }\end{array}$ & 180 & $8.4 \mathrm{E}-21$ & 8.682 \\
\hline & ANGPT2 & $\begin{array}{l}\text { Cell } \\
\text { differentiation, } \\
\text { germ cell } \\
\text { development }\end{array}$ & 85 & $2.84 \mathrm{E}-16$ & 6.092 \\
\hline & VEGFA & $\begin{array}{l}\text { Cell migration, } \\
\text { angiogenesis }\end{array}$ & 102 & $2.05 \mathrm{E}-14$ & 7.275 \\
\hline & EGF & $\begin{array}{l}\text { Potent mitogenic } \\
\text { factor }\end{array}$ & 159 & $7.61 \mathrm{E}-13$ & 8.927 \\
\hline & TGFB3 & $\begin{array}{l}\text { Cell growth and } \\
\text { proliferation }\end{array}$ & 48 & $9.23 \mathrm{E}-11$ & 5.633 \\
\hline & AGT & $\begin{array}{l}\text { Extracellular } \\
\text { matrix } \\
\text { organization }\end{array}$ & 136 & $5.25 \mathrm{E}-10$ & 7.643 \\
\hline & IGF1 & $\begin{array}{l}\text { Cellular } \\
\text { response to } \\
\text { insulin and } \\
\text { glucose }\end{array}$ & 120 & 4.03E-08 & 6.814 \\
\hline & FGF2 & $\begin{array}{l}\text { Cell division and } \\
\text { proliferation }\end{array}$ & 106 & $2.65 \mathrm{E}-07$ & 6.851 \\
\hline & KITLG & $\begin{array}{l}\text { Germ cell } \\
\text { development, } \\
\text { ovarian follicle } \\
\text { development }\end{array}$ & 71 & 4.97E-06 & 5.675 \\
\hline
\end{tabular}

domain containing ETS transcription factor (Spdef), interferon regulatory factor 4 (Irf4), and MAX interactor 1 (Mxil) (Table 4). These transcription regulators are regulators of cell cycle, cell proliferation, chromatin organization and germ cell migration (Table 4). We also identified microRNAs that are likely important in the regulation of self-renewal in EPCs, specifically those that regulate Oct4, Klf4 and Myc (Table 4). Indeed, microRNAs have been reported to play regulatory roles in stem and germ cells [53].

\section{mtDNA copy number and expression of Polg}

EPCs from the current work were harvested from ovaries of mini-pigs from a established colony originating from a single founder female [21], which ensures that each of the offspring inherits the same population of mtDNA. We firstly determined that the mtDNA copy number of EPCs $(1131 \pm 411$, mean \pm SEM $)$ was significantly lower than immature oocytes (Supplementary Data 6) and is within the range for PGC mtDNA copy number 
Table 4: Upstream regulators that negatively regulate EPC gene expression as determined by Ingenuity Pathway Analysis

\begin{tabular}{|c|c|c|c|c|c|c|}
\hline Molecule type & $\begin{array}{l}\text { Upstream } \\
\text { regulator }\end{array}$ & $\begin{array}{l}\text { Biological } \\
\text { function }\end{array}$ & $\begin{array}{l}\text { No. of target } \\
\text { genes }\end{array}$ & P-value & IPA Z-score & Reference (DOI) \\
\hline \multirow[t]{10}{*}{$\begin{array}{l}\text { Transcription } \\
\text { Regulator }\end{array}$} & NUPR1 & Cell cycle & 166 & $3.09 \mathrm{E}-14$ & -3.035 & $\begin{array}{l}\text { IPA Knowledge } \\
\text { database }\end{array}$ \\
\hline & PML & $\begin{array}{l}\text { Regulation } \\
\text { of the TGF- } \\
\text { beta signaling } \\
\text { pathway }\end{array}$ & 58 & $2.22 \mathrm{E}-12$ & -3.195 & $\begin{array}{l}\text { IPA Knowledge } \\
\text { database }\end{array}$ \\
\hline & CDKN2A & $\begin{array}{l}\text { Cell cycle } \\
\text { negative } \\
\text { regulator }\end{array}$ & 100 & 3.37E-11 & -2.147 & $\begin{array}{l}\text { IPA Knowledge } \\
\text { database }\end{array}$ \\
\hline & KLF3 & $\begin{array}{l}\text { Multicellular } \\
\text { organismal } \\
\text { development }\end{array}$ & 112 & $1.48 \mathrm{E}-10$ & -7.504 & $\begin{array}{l}\text { IPA Knowledge } \\
\text { database }\end{array}$ \\
\hline & SMAD7 & $\begin{array}{l}\text { Negative } \\
\text { regulation of } \\
\text { BMP signaling } \\
\text { pathway, } \\
\text { negative } \\
\text { regulation of } \\
\text { cell migration }\end{array}$ & 53 & $8.29 \mathrm{E}-10$ & -4.682 & $\begin{array}{l}\text { IPA Knowledge } \\
\text { database }\end{array}$ \\
\hline & KDM5A & $\begin{array}{l}\text { Chromatin } \\
\text { modification, } \\
\text { chromatin } \\
\text { organization }\end{array}$ & 54 & 2.02E-09 & -5.900 & $\begin{array}{l}\text { IPA Knowledge } \\
\text { database }\end{array}$ \\
\hline & KDM5B & $\begin{array}{l}\text { Chromatin } \\
\text { modification }\end{array}$ & 55 & $3.34 \mathrm{E}-09$ & -4.673 & $\begin{array}{l}\text { IPA Knowledge } \\
\text { database }\end{array}$ \\
\hline & SPDEF & $\begin{array}{l}\text { Germ cell } \\
\text { migration }\end{array}$ & 33 & $3.00 \mathrm{E}-08$ & -4.402 & $\begin{array}{l}\text { IPA Knowledge } \\
\text { database }\end{array}$ \\
\hline & IRF4 & $\begin{array}{l}\text { Interferon- } \\
\text { gamma- } \\
\text { mediated } \\
\text { signaling } \\
\text { pathway }\end{array}$ & 46 & $1.48 \mathrm{E}-04$ & -4.662 & $\begin{array}{l}\text { IPA Knowledge } \\
\text { database }\end{array}$ \\
\hline & MXI1 & $\begin{array}{l}\text { Negatively } \\
\text { regulate MYC } \\
\text { function }\end{array}$ & 10 & $1.51 \mathrm{E}-04$ & -2.919 & $\begin{array}{l}\text { IPA Knowledge } \\
\text { database }\end{array}$ \\
\hline \multirow[t]{3}{*}{$\begin{array}{l}\text { Mature } \\
\text { MicroRNA }\end{array}$} & miR-124-3p & $\begin{array}{l}\text { Potential } \\
\text { regulator of } \\
\text { PIM1 }\end{array}$ & 118 & $1.36 \mathrm{E}-28$ & -10.788 & $\begin{array}{l}\text { Deng et al. } 2016 \\
(10.1111 / \text { cas. } 12946)\end{array}$ \\
\hline & miR-16-5p & $\begin{array}{l}\text { Potential } \\
\text { regulator of } \\
\text { SMAD3 }\end{array}$ & 102 & $1.23 \mathrm{E}-24$ & -9.938 & $\begin{array}{l}\text { Li et al. } 2015(10.21 \\
74 / 13816128216661 \\
50909094712)\end{array}$ \\
\hline & miR-1-3p & Unknown & 99 & $5.58 \mathrm{E}-24$ & -9.767 & $\mathrm{n} / \mathrm{a}$ \\
\hline
\end{tabular}




\begin{tabular}{|c|c|c|c|c|c|c|}
\hline Molecule type & $\begin{array}{l}\text { Upstream } \\
\text { regulator }\end{array}$ & $\begin{array}{l}\text { Biological } \\
\text { function }\end{array}$ & $\begin{array}{c}\text { No. of target } \\
\text { genes }\end{array}$ & P-value & IPA Z-score & Reference (DOI) \\
\hline & let-7a-5p & $\begin{array}{l}\text { Potential } \\
\text { regulator of } \\
\text { CCND1 and } \\
\text { MYC }\end{array}$ & 78 & $7.77 \mathrm{E}-20$ & -8.622 & $\begin{array}{l}\text { Ghanbari et al. } \\
2015 \text { (10.4137/BIC. } \\
\text { S25252) }\end{array}$ \\
\hline & $\operatorname{miR}-30 c-5 p$ & $\begin{array}{l}\text { Potential } \\
\text { regulator of } \\
\text { EIF2A }\end{array}$ & 63 & $2.14 \mathrm{E}-19$ & -7.805 & $\begin{array}{l}\text { Jiang et al. } 2016 \\
\text { (10.1038/srep21565) }\end{array}$ \\
\hline & miR-155-5p & $\begin{array}{l}\text { Potential } \\
\text { regulator of } \\
\text { DNMT1 }\end{array}$ & 73 & $1.24 \mathrm{E}-15$ & -8.437 & $\begin{array}{l}\text { Zhang et al. } 2015 \\
\text { (10.1093/nar/ } \\
\text { gkv518) }\end{array}$ \\
\hline & $\operatorname{miR}-483-3 p$ & $\begin{array}{l}\text { Potential } \\
\text { regulator of } \\
\text { CDC25A }\end{array}$ & 25 & $2.50 \mathrm{E}-08$ & -4.969 & $\begin{array}{l}\text { Bertero et al. } \\
2013(10.1038 / \\
\text { cdd.2013.5) }\end{array}$ \\
\hline & $\operatorname{miR}-133 a-3 p$ & $\begin{array}{l}\text { Potential } \\
\text { regulator of } \\
\text { RBPJ }\end{array}$ & 27 & $5.27 \mathrm{E}-08$ & -5.065 & $\begin{array}{l}\text { Huang et al. } 2016 \\
\text { (ISSN:2156-6976/ } \\
\text { ajcr0040390/; } \\
\text { PMID: 27904763) }\end{array}$ \\
\hline & miR-145-5p & $\begin{array}{l}\text { Potential } \\
\text { regulator of } \\
\text { OCT4 and } \\
\text { KLF4 }\end{array}$ & 29 & $8.90 \mathrm{E}-08$ & -5.312 & $\begin{array}{l}\text { Xu et al. } 2009 \\
(10.1016 / \mathrm{j} . \\
\text { cell.2009.02.038) }\end{array}$ \\
\hline & miR-29b-3p & $\begin{array}{l}\text { Potential } \\
\text { regulator of } \\
\text { TGFB1 }\end{array}$ & 29 & $5.48 \mathrm{E}-07$ & -5.260 & $\begin{array}{l}\text { Lu et al. } 2016 \\
(10.1096 / \\
\text { fj.201600722R) }\end{array}$ \\
\hline
\end{tabular}

$[41-43,54]$. We then determined the expression levels of mitochondrial specific polymerase gamma ( $\mathrm{Polg}$ ) in mini-pig heart, muscle and EPCs, and found that EPCs express significantly fewer transcripts than heart tissues (Supplementary Data 7). These data show that EPCs maintain low mtDNA copy number, which is indicative of their naïve state.

\section{mtDNA sequence variants harbored by the EPCs}

To determine the number of positions within the mitochondrial genome that harbored a sequence variant, we performed in depth Next Generation Sequencing with $>4000$ times coverage. MtDNA sequence variants that were harbored between 3 to $50 \%$ were compared amongst EPCs, oocytes, 2-cell embryos, 4-cell embryos, 8-cell embryos and ovarian tissues (Table 5). Eighteen positions within the mitochondrial genome were affected, with the mean number of variants harbored by EPCs, oocytes, 2-cell embryos, 4-cell embryos, 8-cell embryos and ovarian tissues being 7.3, 2.9, 3.5, 3, 3 and 2.6, respectively (Table 5). EPCs harbored the most number of variants, whilst ovarian tissues had the least. The variant A376del was harbored by all samples and at a mean frequency of $4.6 \pm 0.1 \%$ (mean \pm S.E.M), as was A5188del at a mean frequency of $4.8 \pm 0.08 \%$ (mean \pm S.E.M). This indicates that some variants that are present at low levels can persist from oogenesis through embryo development to adulthood. Moreover, the variant T7317C was harbored only by EPCs and oocytes and this variant was harbored at relatively high frequencies. This demonstrates that EPCs and oocytes possessed a similar population of mtDNA. However, the $\mathrm{T} 7317 \mathrm{C}$ variant is eliminated post-fertilization but persists in putative germline cells. The A1253del variant was also found across all groups, but found less frequently in EPCs (25\%) compared with oocytes (65\%), embryos (100\%) and ovarian tissues $(60 \%)$.

We then compared the variants with those that we had previously identified in our mini-pig model [21]. The A376del was harbored by oocytes, preimplantation embryos and somatic tissues, and was maintained in our mini-pig colony over three generations, which was derived from one common maternal ancestor. Specifically, in the immature $(\sim 10 \%)$ and mature $(\sim 20 \%)$ oocytes and embryos $(\sim 50 \%)$, the levels of A376del were very different. However, in somatic tissues the variant was present at low levels $(<20 \%)$ across three generations in all tissues examined. This suggests that this variant is present in the germline and is regulated at different stages of development in the offspring [21]. 
Table 5: Mitochondrial DNA sequence variants in EPCs, oocytes, 2-cell embryos, 4-cell embryos, 8-cell embryos and ovarian tissues

\begin{tabular}{|c|c|c|c|c|c|c|c|c|c|c|c|c|c|c|c|c|c|c|c|c|c|c|c|c|c|c|c|c|c|c|c|c|c|c|}
\hline \multirow{2}{*}{ Position } & \multirow{2}{*}{ WT } & \multirow{2}{*}{$\mathbf{v}$} & \multirow{2}{*}{ Gene } & \multicolumn{4}{|c|}{ EPC } & \multicolumn{16}{|c|}{ Immature oocytes } & \multicolumn{2}{|c|}{2 cell } & \multicolumn{2}{|c|}{4 cell } & \multicolumn{2}{|c|}{8 cell } & \multicolumn{5}{|c|}{ Ovarian tissue } \\
\hline & & & & A1 & A2 & A3 & $\mathrm{A4}$ & L1 & L2 & L3 & L4 & L5 L & $\begin{array}{lll}\text { L6 L } & \text { L }\end{array}$ & L7 L8 & $48 \quad$ L9 & L10 & L11 & L12 & L13 & L14 & L15 & L16 & L17 & E13 & $\overline{\text { E14 }}$ & E18 & E19 & E23 & $\overline{E 24}$ & 01 & 02 & 03 & 04 & 05 \\
\hline 376 & A & - & 12s RNA & 3.2 & 3.3 & 3.4 & 4.2 & 4.5 & 4.5 & 4.0 & 4.8 & $4.7 \quad 4$ & $4.7 \quad 4$ & $\begin{array}{ll}4.8 \quad 4.6 \\
-1\end{array}$ & 1.64 .8 & 5.0 & 5.1 & 5.0 & 4.7 & 4.9 & 5.8 & 5.5 & 4.7 & 5.2 & 4.7 & 4.9 & 5.5 & 4.8 & 4.8 & 5.1 & 4.6 & 4.5 & 4.4 & 4.0 \\
\hline 960 & $\mathrm{~T}$ & $\mathrm{C}$ & 12s RNA & & & & & & & & & & & & & & & & & & & & & 7.0 & & & & & & & & & & \\
\hline 1253 & A & - & 16s RNA & 9.3 & & & & 3.2 & & & & & 3.1 & 3.1 & 1.13 .1 & 3.4 & 3.4 & 3.6 & 3.4 & 3.4 & 3.6 & & 3.2 & 3.4 & 3.3 & 3.4 & 3.6 & 3.6 & 3.3 & 3.5 & 3.0 & 3.4 & & \\
\hline 1497 & - & A & 16s RNA & & & & & & & 8.2 & & & & & & & & & & & & & & & & & & & & & & & & \\
\hline 3256 & G & A & NADH1 & & & & 3.8 & & & & & & & & & & & & & & & & & & & & & & & & & & & \\
\hline 3495 & A & G & NADH1 & & 8.8 & & & & & & & & & & & & & & & & & & & & & & & & & & & & & \\
\hline 4932 & C & $\mathrm{T}$ & $\mathrm{NADH} 2$ & & 4.2 & & & & & & & & & & & & & & & & & & & & & & & & & & & & & \\
\hline 5188 & A & - & $\begin{array}{l}\text { Origin of } \\
\text { L-strand } \\
\text { replication }\end{array}$ & 3.5 & 4.7 & 4.6 & 4.0 & 5.0 & 4.4 & 5.1 & $\begin{array}{ll}5.3 \quad 5\end{array}$ & 5.14. & 4.94. & $4.7 \quad 4.6$ & $\begin{array}{ll}1.6 & 4.8\end{array}$ & 4.8 & 5.0 & 5.2 & 4.7 & 5.0 & 4.7 & 4.2 & 4.4 & 5.6 & 4.6 & 5.1 & 4.8 & 4.6 & 4.4 & 5.1 & 5.2 & 5.4 & 5.0 & 4.4 \\
\hline 7317 & $\mathrm{~T}$ & $\mathrm{C}$ & COII & 8.2 & 4.3 & & 12.8 & & & & & & & 5.1 & 3.7 & & & 7.7 & & 19.3 & & & & & & & & & & & & & & \\
\hline 12101 & C & $\mathrm{T}$ & NADH5 & & & & 4.5 & & & & & & & & & & & & & & & & & & & & & & & & & & & \\
\hline 12535 & $\mathrm{~T}$ & A & NADH5 & & 4.2 & & & & & & & & & & & & & & & & & & & & & & & & & & & & & \\
\hline 12860 & A & G & NADH5 & & & 3.4 & & & & & & & & & & & & & & & & & & & & & & & & & & & & \\
\hline 15760 & $\mathrm{~T}$ & C & $\begin{array}{l}\text { Control } \\
\text { region }\end{array}$ & & & 9.5 & & & & & & & & & & & & & & & & & & & & & & & & & & & & \\
\hline 16022 & $\mathrm{~T}$ & C & $\begin{array}{c}\text { Control } \\
\text { region }\end{array}$ & 3.7 & & & & & & & & & & & & & & & & & & & & & & & & & & & & & & \\
\hline 16140 & A & G & $\begin{array}{l}\text { Control } \\
\text { region }\end{array}$ & & 6.9 & 4.9 & 3.1 & & & & & & & & & & & & & & & & & & & & & & & & & & & \\
\hline 16142 & A & G & $\begin{array}{c}\text { Control } \\
\text { region }\end{array}$ & & 6.7 & 4.6 & & & & & & & & & & & & & & & & & & & & & & & & & & & & \\
\hline 16352 & A & G & $\begin{array}{c}\text { Control } \\
\text { region }\end{array}$ & 5.0 & 7.5 & 4.6 & & & & & & & & & & & & & & & & & & & & & & & & & & & & \\
\hline 16561 & A & G & $\begin{array}{c}\text { Control } \\
\text { region }\end{array}$ & & 4.0 & & & & & & & & & & & & & & & & & & & & & & & & & & & & & \\
\hline
\end{tabular}

Footnote: $\mathrm{WT}=$ wild type; $\mathrm{V}=$ variant.

\section{DISCUSSION}

Mitochondrial supplementation, otherwise known as mICSI, is a relatively new assisted reproductive technique that has the potential to have a significant impact on the treatment of female-factor infertility. This technique arose from the concept of ooplasmic transfer from younger to older women as a means to rescue poor quality oocytes [55]. To perform mICSI, purified mitochondria without accompanying mRNA and other cellular factors are injected into the cytoplasm of metaphase II oocytes along with the spermatozoa during the process of ICSI [22]. The technique of ICSI has been performed for nearly three decades and has led to the birth of over 2.5 million children [3]. Whilst ICSI has successfully treated malefactor infertility, especially those associated with poor or abnormal semen quality, it does not improve pregnancy outcomes for women over the age of 40 [4] or for mtDNA deficiency [22].

We have previously shown that by performing mICSI in our porcine model of mtDNA-deficient oocytes, supplementation of 800 copies of mtDNA resulted in a significant (4.4 fold) increase of mtDNA copy number at the 2-cell embryo stage [22]. This is important as it ensures sufficient copies are allocated to each blastomere as they divide [15]. Moreover, the global gene expression profiles of the resultant blastocysts from mtDNAdeficient oocytes were enhanced to resemble blastocysts derived from mtDNA-normal oocytes [22]. However, the mitochondria isolated from our previous work were derived from metaphase II oocytes. The present work assesses the suitability of utilizing EPCs for mitochondrial supplementation by determining their origins through their gene expression profiles and the mtDNA variants they harbor. As a consequence, this will also define their suitability for transplantation purposes to restore ovarian function for women with, for example, premature ovarian failure.

Here, we have cultured isolated EPCs for one week, without passage, and observed that they were not dormant and were able to proliferate under in vitro conditions. We then assessed the gene expression profiles of EPCs, and found that they shared some key markers with porcine PGCs [47]. They express primitive germ cell specific markers Fragilis [36] and Tert, which is the enzymatic component of telomerase and is highly expressed in germline stem cells [56]. The expression of Fragilis and 
Tert was also found in human mitotically active post-natal germ cells [27, 48]. Interestingly, Fragilis was the only primitive germ cell marker that was consistently detected in mouse and pig putative germline stem cells $[28,50]$. However, we did not observe the expression of Blimp1 or Stella, which are other primitive germ cell markers $[36,57]$. We argue that since Blimpl and Stella are only expressed in a small proportion of Fragilis positive cells $[36,57]$, the gene expression levels in the isolated porcine EPCs may be very low. Nevertheless, the expression of $D d x 4$, which encodes for the evolutionarily conserved and germ cell specific VASA protein $[39,58]$, was detected in the EPCs, albeit at low levels.

The discovery of mitotically active ovarian stem cells has challenged the widely accepted view that the ovarian reserve is fixed at birth (approximately 1 million follicles) and cannot be renewed [25, 59, 60]. The existence of ovarian stem cells was initially reported in mice [26], and subsequently found in human ovarian cortical tissues [27]. Since then putative ovarian stem cells have been isolated by multiple groups and in several species $[28,49,50]$. Ovarian stem cells have the capacity to proliferate, differentiate to oocyte-like cells and can be fertilized to produce live offspring [27, 34, 35]. We chose to use cells that had been cultured in order to undertake our analysis on cells that had the propensity to proliferate and were not trapped in a dormant state, which is a key characteristic that we would expect from cells with the potential to give rise to more mature cell types. However, they may change their characteristics or selected for particular sub-groups.

In the present work, of the core pluripotency markers, EPCs only expressed Nanog but not Sox2 or Oct4. However, cell proliferation and self-renewal markers such as Myc, Esrrb, Zfx, Id2, Klf4, Klf5, Tbx3, Stat3, Fgfr1, Fgfr2, Lifr, and Pparg were expressed. It is important to note that expression of the pluripotency network genes varies between species, as demonstrated in human and mouse embryonic stem cells [61]. Therefore, extrapolation of results from pig, mouse and human should be taken with caution. Nevertheless, the cell cycle markers Cdk1, Cdk2, Rpa1, Rabgap1, and App were also expressed. From culturing the cells prior to RNA extraction and from PANTHER gene enrichment analysis and IPA pathway analysis, we have found that EPCs have the propensity to undergo cell proliferation and utilize canonical pathways that are important for germ cell development. This is an unexpected finding, since, after a proliferative phase, PGCs enter and arrest at the diplotene stage of prophase I of meiosis, thereby ending their proliferative capacity [38]. Moreover, we did not observe the expression of $Z p 1$, $Z p 2, Z p 3$ or Fig $\alpha$, which are required for differentiation to primordial oocytes $[62,63]$. Therefore, we suggest that these EPCs are undifferentiated multipotent lineagespecific oogonial cells, that could differentiate into oocytes or be dedifferentiated under the right conditions.
Interestingly, one of the top canonical pathways that was utilized by the EPCs was the mTOR signaling pathway, which is important for the maintenance of embryonic stem cells and is embryonically lethal when knocked-out [64]. We have also detected the expression of $c$-kit, which is a protein kinase receptor responsible for the reawakening of the quiescent primordial follicle to enter follicular growth, via the PI3K-AKT pathway [65], which is one of the top canonical pathway used, demonstrating the potential of EPCs to enter follicular development.

mtDNA is clonally amplified from 200 copies in PGCs to $>150,000$ copies in metaphase II oocytes [19, $41-43,66,67]$, which represents the potential number of molecules of the mitochondrial genome available for transmission to offspring. Two or more populations of mtDNA genotypes (wild type and molecules harboring variants) can co-exit, but variants normally exist at low levels in healthy individuals $[21,68]$. Indeed, numerous studies have shown that pathogenic and non-pathogenic mtDNA variants are more prevalent in humans than previously thought [68-70]. Individuals remain healthy until pathogenic mtDNA variants pass a certain threshold, whereby wild-type mtDNA can no longer compensate for defective mtDNA [44]. Therefore, to ensure that EPCs possess the same mtDNA genotypes as oocytes, for the faithful transmission of germline mtDNA to offspring during assisted reproduction, we compared mtDNA variants harbored by mini-pig EPCs, oocytes, embryos, and ovarian tissues. We found that mtDNA sequence variants A376del, A1253del and A5188del were present in all samples at low percentages. On the other hand, the T7317C variant is harbored by the EPCs and oocytes at high percentages, but was not detected in embryos or ovarian tissues. To this end, our data on A376del, A1253del and A5188del indicate that oocytes and EPCs originate from the same lineage during early development and are recycled from one generation to the next as indicated by their presence in gametes, embryos and tissues. However, it appears that the T7317C variant was diluted out during embryo development [41, 43, 71].

From human studies and our mini-pig model, it has been shown that certain mtDNA variants tend to accumulate at a higher percentage in specific tissues [21, $69,70]$. In the present work, we found that the variants 1497InsA and T960C may have resulted from replication errors made by POLG [72], or were preferentially amplified during early embryo development [71], but they were not observed in the adult ovarian tissues. Only the variant A376del is consistently detected across EPCs, oocytes, embryos, as well as somatic tissues such as ovarian tissues, heart and brain [21], which suggests that this variant arose from the germline and is maintained in both germ cells and somatic tissues. Nevertheless, we found that the de novo acquisition of mtDNA variants is not very common in our mini-pig model. Therefore, our results indicate that EPCs harbor variants that originated 
from the germline. In addition, we suggest that it is important to faithfully transmit those variants to offspring, since they may be advantageous during development, and/or for maintaining natural genetic variation in the population [21]. Whilst mouse models possessing two genetically divergent non-pathogenic mtDNA genotypes have perturbed physiological functions [73], the exact role of endogenous non-pathogenic mtDNA variants is still unclear. Furthermore, our mini-pig model is not known to carry any mitochondrial disease causing mutations.

Accumulation of mtDNA variant load is associated with aging and other age-related disorders $[44,74]$. There is also evidence to suggest that mtDNA variant load increases in oocytes and cumulus cells of women over the age of 35 $[9,75,76]$. To this end, EPCs represent an ideal population of cells for mitochondrial isolation to be used in the clinic, as they are genetically identical to the patient and harbor a low percentage of mtDNA variants. Since the proportion of mtDNA variants has been shown to increase in culture after each passage [77], we cultured the EPCs for one week without passage. This is beneficial for clinical applications, as a proportion of the viable EPCs could be used to screen for pathogenic mtDNA variants prior to mICSI. In this respect, EPCs are also a source of "ovarian stem cells", or for generating "oocyte-like cells" to be used for ovarian transplantation. We found that mtDNA copy number of EPCs is within the previously reported range for PGCs [41-43]. This suggests that the mitochondria they reside in have low mitochondrial metabolic activity, as is the case for stem-like cells that primarily rely on glycolysis for energy production [78]. Furthermore, in agreement with our copy number data, EPCs express significantly fewer Polg transcripts compared with heart tissues.

In conclusion, we have characterized the gene expression profiles of EPCs by RNA-sequencing and performed gene enrichment analysis and pathway analysis to determine that EPCs possess proliferative and self-renewal capacity. The main aim of the current study was to determine whether EPCs are a suitable source to harvest naïve mitochondria to be used in mitochondrial supplementation during mICSI. We have achieved this aim by showing that EPCs possess mtDNA variants that are distinctive to the germline lineage. This unique population of cells could be used for in vitro maturation or ovarian transplantation to allow women with low ovarian reserve and/or hormone sensitivity to conceive. Furthermore, characterization of ovarian stem cells is important for our fundamental understanding of ovarian biology and the process of ovarian ageing.

\section{MATERIALS AND METHODS}

\section{Animal ethics approval}

Tissues obtained from mini-pigs were excess to requirement. Animals were euthanized in accordance with animal ethics guidelines. Approval for the use of animals was granted by Monash Medical Centre Animal Ethics Committee A, approval number MMCA/2012/84.

\section{Preparation of ovarian cortical strips from porcine tissue}

Porcine ovaries were transported to the laboratory in sterile phosphate buffered saline (Sigma-Aldrich, St Louis, $\mathrm{MO}$, U.S.A), and maintained at $\sim 38^{\circ} \mathrm{C}$. Ovaries were cut in half lengthways and transferred to a sterile $10 \mathrm{~cm}$ dish containing phosphate buffered saline with penicillin and streptomycin. Avoiding the central cortex area, bisected ovaries were cut into thin slices using a carbon steel single edge razor blade. A size 10 or 11 scalpel blade was used to cut the ovary slices into strips, and then each strip was cut into small pieces. Approximately 30 pieces of ovarian tissue were washed and transferred to a cryovial containing $1 \mathrm{ml}$ of sterile, $90 \% \mathrm{FBS} / 10 \%$ DMSO freezing solution to be frozen overnight at $-80^{\circ} \mathrm{C}$, then transferred to $\mathrm{LN}_{2}$ tank for storage.

\section{Fluorescence-activated cell sorting}

Porcine ovarian cortex tissue was digested and processed into a single cell suspension, based on methods described previously [48]. In brief, cells were resuspended and blocked in $2 \%$ human serum albumin (HSA) in HBSS (without $\mathrm{Mg}^{2+}$ and $\mathrm{Ca}^{2+}$ ) for $20 \mathrm{~min}$ at room temperature with agitation followed by an incubation with Alexa Fluor ${ }^{\circledR}$ 647-conjugated anti-DDX4 antibody (HuMab DDX4) for $20 \mathrm{~min}$ at room temperature (in the dark) at a concentration of $10 \mu \mathrm{g}$ per million cells per $100 \mu \mathrm{l}$. The cell suspension was washed by centrifugation in HBSS (without $\mathrm{Mg}^{2+}$ and $\mathrm{Ca}^{2+}$ ) followed by incubation with SYTOX ${ }^{\circledR}$ green dead cell stain (Cat \# S34860, ThermoFisher) at $30 \mu \mathrm{M}$ for $20 \mathrm{~min}$ at room temperature with agitation (in the dark). For each experiment, an aliquot of unstained cells was used as the negative threshold and gating control. Labeled cells were filtered ( $35 \mu \mathrm{m}$ pore diameter) and subjected to analysis on an SH800 flow cytometer with the manufacturer's SH800 software (Sony Biotechnology Inc., San Jose, CA, USA). Freshly isolated DDX4 positive viable cells (EPCs) were collected and frozen in cryopreservation buffer.

\section{Porcine EPC culture}

The cells derived from porcine ovarian cortical strips were cultured in EPC media consisting of DMEM, supplemented with $10 \%$ FBS (heat inactivated), 1 $\mathrm{mM}$ sodium pyruvate, $1 \mathrm{mM}$ nonessential amino acids, 1X penicillin-streptomycin-glutamine, $0.1 \mathrm{mM}$ $\beta$-mercaptoethanol (all ThermoFisher Scientific), $10^{3}$ units/ml ESGRO leukemia inhibitory factor (LIF), 10 $\mathrm{ng} / \mathrm{ml}$ recombinant human epidermal growth factor (rhEGF), $1 \mathrm{ng} / \mathrm{ml}$ basic fibroblast growth factor (bFGF), $40 \mathrm{ng} / \mathrm{ml}$ glial cell-derived neurotropic factor (GDNF; all Merck Millipore) and 1X N-2 MAX supplement (R \& D Systems). On thawing, cells were plated at a density of 
$2.5 \times 10^{4} / \mathrm{cm}^{2}$ in EPC media at $39^{\circ} \mathrm{C}$ and $5 \% \mathrm{CO}_{2}$ with media changes every 2 days. Once confluent, cells were lysed directly in the wells, lysates collected, snap frozen in $\mathrm{LN}_{2}$ and stored at $-80^{\circ} \mathrm{C}$ until processed further for RNA extraction using the RNeasy Mini Kit (Qiagen), as per manufacturer's instructions.

\section{RNA library preparation and sequencing}

Library preparation was performed using the TruSeq RNA v2 (Illumina, CA, USA) protocol. Briefly, mRNA was purified using oligo(dT) beads, and then fragmented. The $1^{\text {st }}$ strand cDNA synthesis was randomly primed followed by $2^{\text {nd }}$ strand cDNA synthesis. Sequencing adaptors were ligated and the library was amplified by PCR. RNA sequencing was performed on a HiSeq 3000 (Illumina). Sequencing data were deposited in the sequence read archive (SRA) in NCBI under the project number PRJNA374593.

\section{RNA sequencing bioinformatics analysis}

$46 \pm 0.9($ mean \pm S.E.M) million paired reads were obtained from RNA sequencing. Read quality was determined by the Illumina quality score, with $>92 \%$ bases above Q30 across all five samples. Adaptor and overrepresented sequences were removed before the sequence reads were aligned to the pig reference genome (NCBI version: GCF_000003025.5_Sscrofa10.2). Using the Stringtie tool $\mathrm{v} \overline{1} .0 .4,79.7 \pm \overline{0} .4$ (mean \pm S.E.M) $\%$ of the paired reads were mapped to the Sus scrofa exons. Data normalization was performed using edgeR. 13,808 normalized and annotated genes were identified. To determine the overall functions of EPCs, normalized RNA-Sequencing data were analyzed using the PANTHER classification system (http://www.pantherdb. org/) [79]. Ingenuity Pathway Analysis (IPA) (QIAGEN Redwood City, www.giagen.com/ingenguity, fall 2016 release), which is a web-based application, was used to determine pathways utilized by the EPCs. "Commonly Expressed Genes" tool was applied to the dataset $(\mathrm{n}=5)$ to identify common genes. A further cutoff of 5-log ratio was applied and 4391 genes were used for pathway analysis to identify highly expressed genes.

\section{Real time PCR for estimation of mtDNA copy number}

Each PCR reaction consisted of $2 \mu \mathrm{L}$ of template DNA, $10 \mu \mathrm{L}$ of $2 \mathrm{x}$ SensiMix (Bioline), $1 \mu \mathrm{L}$ of $5 \mu \mathrm{M}$ of each forward (5'-CTCAACCCTAGCAGAAACCA-3') and reverse primer (5'-TTAGTTGGTCGTATCGGAATCG-3'), and 6 $\mu \mathrm{L}$ of ultrapure ddH20, performed in a Rotergene-3000 real time PCR machine (Corbett Research, Cambridge, UK). A series of 10 -fold dilutions ( $1 \mathrm{ng} / \mu \mathrm{L}$ to $1 \mathrm{x} 10-8$ $\mathrm{ng} / \mu \mathrm{L}$ ) was used as the known standards. mtDNA quantification was determined from the standard curve, and mtDNA copy number was calculated based on the PCR product length.

\section{Reverse transcriptase PCR}

RNA from oocytes, blastocysts and EPCs was isolated using the ARCTURUS $\AA$ PicoPure $\AA$ RNA Isolation Kit (ThermoFisher Scientific), as per manufacturer's instructions. First strand cDNA synthesis was performed using the qScript Flex cDNA kit (Quantabio, MA, U.S.A), according to manufacturer's protocol. The resultant cDNA was used to amplify target genes by PCR (Primer sequences; Supplementary Table 1). The expression of $D d x 4$ was confirmed by Sanger sequencing using a previously described protocol [66].

\section{mtDNA amplification and purification}

The whole mitochondrial genome from EPC isolates $(n=4)$, immature oocytes $(n=17), 2$-cell embryos $(n=2)$, 4-cell embryos $(n=2)$, 8-cell embryos $(n=2)$ and ovarian tissues $(n=5)$ were amplified by long PCR, as previously described [66]. Briefly, 40 ng DNA, with $1 \times$ High Fidelity PCR buffer, $100 \mathrm{mM}$ MgSO4, $1 \mathrm{mM}$ dNTPs (Bioline), $1 \mathrm{U}$ of Platinum Taq High Fidelity (Invitrogen, CA, USA) and $10 \mu \mathrm{M}$ of each forward and reverse primer (Primer sequences; Supplementary Table 1). PCR products were separated on a $0.7 \%$ agarose gel and purified using the QIAquick PCR Purification Kit (Qiagen, West Sussex, UK).

\section{Whole mitochondrial genome sequencing}

The DNA concentration of purified long PCR products was determined by Qubit ${ }^{\circledR}$ dsDNA HS Assay kit (Invitrogen). For each sample, equal amounts of DNA were pooled from PCR product A and B ( $\sim 5 \mathrm{ng}$ combined). DNA shearing was performed by sonication using the S220 Focused-ultrasonicator (Covaris, MA, USA) to generate a mean library size of $\sim 400 \mathrm{bp}$. Libraries were prepared with Ovation Ultralow system V2 (protocol M01380v1) (Nugen, CA, USA). 14 cycles of amplification were performed. Sequencing was performed using the $250 \mathrm{bp}$ paired-end chemistry on the Illumina MiSeq v2 platform with PhiX spike-in for technical control. The MiSeq run generated a total of 22.8 million reads that passed filter. Each of the four samples generated 785,599 \pm 22390 (mean \pm S.E.M) reads.

\section{Identification of mtDNA sequence variants}

Two FASTQ files for each sample were imported into CLC Genomics Workbench v9.5.1 for quality trimming. Duplicate reads were removed before the remaining reads were mapped to a reference pig mitochondrial genome AJ002189 [12] to generate a representative sequence. Read sequences were then 
mapped to the representative sequence without masking, with an insertion and deletion cost of 3 and minimum of $80 \%$ identity to the representative sequence. The low frequency variant detection tool was used to determine the level of sequence variants. Variant calling was made using the following parameters: $3 \%$ minimum threshold, presence of variant on forward and reverse reads. Each variant identified, had a minimum count of 140, within minimum sequence coverage of 4000 .

\section{Statistical analysis}

Data analysis was performed using GraphPad Prism v6.0f (GraphPad Software, Inc., CA, USA). mtDNA copy number between EPCs and immature oocytes was compared using Mann-Whitney test. Polg expression amongst EPCs, and heart and muscle tissues was compared using ordinary one-way ANOVA followed by Dunn's multiple comparisons test.

\section{Author contributions}

TT performed Next Generation Sequencing analysis, participated in the design of the experiment, performed molecular analysis and wrote the manuscript. $J J$ performed cell culture and contributed to the writing of the manuscript. $Y W$ performed FAC sorting and contributed to the writing of the manuscript. JCSJ conceived the work, designed and coordinated the experiments, analyzed the data and wrote the manuscript.

\section{ACKNOWLEDGMENTS}

We are grateful to Lori McPartlin (OvaScience, Inc.) for technical assistance with FACS sorting.

\section{CONFLICTS OF INTEREST}

$Y W$ is an employee and stock holder of OvaScience Inc. Ovascience did not fund or influence the content of the manuscript. $T T, J J$ and JCSJ declare no conflicts of interest.

\section{FUNDING}

The work was funded by The Hudson Special Projects Fund and the Victorian Government's Operational Infrastructure Support Program.

\section{REFERENCES}

1. Navot D, Bergh PA, Williams MA, Garrisi GJ, Guzman I, Sandler B, Grunfeld L. Poor oocyte quality rather than implantation failure as a cause of age-related decline in female fertility. Lancet. 1991; 337:1375-1377.
2. Balasch J. Ageing and infertility: an overview. Gynecol Endocrinol. 2010; 26:855-860.

3. Van Steirteghem A. Celebrating ICSI's twentieth anniversary and the birth of more than 2.5 million children-the 'how, why, when and where'. Hum Reprod. 2012; 27:1-2.

4. Tannus S, Son WY, Gilman A, Younes G, Shavit T, Dahan $\mathrm{MH}$. The role of intracytoplasmic sperm injection in nonmale factor infertility in advanced maternal age. Hum Reprod. 2017; 32:119-124.

5. Wilding M. Potential long-term risks associated with maternal aging (the role of the mitochondria). Fertil Steril. 2015; 103:1397-1401.

6. Keefe DL, Niven-Fairchild T, Powell S, Buradagunta S. Mitochondrial deoxyribonucleic acid deletions in oocytes and reproductive aging in women. Fertil Steril. 1995; 64:577-583.

7. Santos TA, El Shourbagy S, St John JC. Mitochondrial content reflects oocyte variability and fertilization outcome. Fertil Steril. 2006; 85:584-591.

8. May-Panloup P, Chrétien MF, Jacques C, Vasseur C, Malthièry Y, Reynier P. Low oocyte mitochondrial DNA content in ovarian insufficiency. Hum Reprod. 2005; 20:593-597.

9. Rebolledo-Jaramillo B, Su M, Stoler N, McElhoe JA, Dickins B, Blankenberg D, Korneliussen TS, Chiaromonte F, Nielsen R, Holland MM. Maternal age effect and severe germ-line bottleneck in the inheritance of human mitochondrial DNA. Proc Natl Acad Sci U S A. 2014; 111:15474-15479.

10. Van Blerkom J. Mitochondria in early mammalian development. Semin Cell Dev Biol. 2009; 20:354-364.

11. Saben JL, Boudoures AL, Asghar Z, Thompson A, Drury A, Zhang W, Chi M, Cusumano A, Scheaffer S, Moley KH. Maternal metabolic syndrome programs mitochondrial dysfunction via germline changes across three generations. Cell Rep. 2016; 16:1-8.

12. Ursing BM, Arnason U. The complete mitochondrial DNA sequence of the pig (Sus scrofa). J Mol Evol. 1998; 47:302-306.

13. Anderson S, Bankier AT, Barrell BG, de Bruijn $\mathrm{MH}$, Coulson AR, Drouin J, Eperon IC, Nierlich DP, Roe BA, Sanger F, Schreier PH, Smith AJ, Staden R, Young IG. Sequence and organization of the human mitochondrial genome. Nature. 1981; 290:457-465.

14. Kelly RD, Mahmud A, McKenzie M, Trounce IA, St John JC. Mitochondrial DNA copy number is regulated in a tissue specific manner by DNA methylation of the nuclearencoded DNA polymerase gamma A. Nucleic Acids Res. 2012; 40:10124-10138.

15. St John J. The control of mtDNA replication during differentiation and development. Biochimica et Biophysica Acta. 2014; 1840:1345-1354. 
16. Reynier P, May-Panloup P, Chrétien MF, Morgan CJ, Jean $\mathrm{M}$, Savagner F, Barrière $\mathrm{P}$, Malthièry Y. Mitochondrial DNA content affects the fertilizability of human oocytes. Mol Hum Reprod. 2001; 7:425-429.

17. Murakoshi Y, Sueoka K, Takahashi K, Sato S, Sakurai T, Tajima H, Yoshimura Y. Embryo developmental capability and pregnancy outcome are related to the mitochondrial DNA copy number and ooplasmic volume. J Assist Reprod Genet. 2013; 30:1367-1375.

18. Chan CC, Liu VW, Lau EY, Yeung WS, Ng EH, Ho PC. Mitochondrial DNA content and 4977 bp deletion in unfertilized oocytes. Mol Hum Reprod. 2005; 11:843-846.

19. Spikings EC, Alderson J, St John JC. Regulated mitochondrial DNA replication during oocyte maturation is essential for successful porcine embryonic development. Biol Reprod. 2007; 76:327-335.

20. El Shourbagy SH, Spikings EC, Freitas M, St John JC. Mitochondria directly influence fertilisation outcome in the pig. Reproduction. 2006; 131:233-245.

21. Cagnone G, Tsai TS, Srirattana K, Rossello F, Powell DR, Rohrer G, Cree L, Trounce IA, St John JC. Segregation of naturally occurring mitochondrial DNA variants in a minipig model. Genetics. 2016; 202:931-944.

22. Cagnone GL, Tsai TS, Makanji Y, Matthews P, Gould J, Bonkowski MS, Elgass KD, Wong AS, Wu LE, McKenzie M, Sinclair DA, St John JC. Restoration of normal embryogenesis by mitochondrial supplementation in pig oocytes exhibiting mitochondrial DNA deficiency. Sci Rep. 2016; 6:23229.

23. Pagnamenta AT, Taanman JW, Wilson CJ, Anderson NE, Marotta R, Duncan AJ, Bitner-Glindzicz M, Taylor RW, Laskowski A, Thorburn DR, Rahman S. Dominant inheritance of premature ovarian failure associated with mutant mitochondrial DNA polymerase gamma. Hum Reprod. 2006; 21:2467-2473.

24. Boucret L, Chao de la Barca JM, Morinière $C$, Desquiret V, Ferré-L'Hôtellier V, Descamps P, Marcaillou C, Reynier P, Procaccio V, May-Panloup P. Relationship between diminished ovarian reserve and mitochondrial biogenesis in cumulus cells. Hum Reprod. 2015; 30:1653-1664.

25. Faddy MJ, Gosden RG, Gougeon A, Richardson SJ, Nelson JF. Accelerated disappearance of ovarian follicles in midlife: implications for forecasting menopause. Hum Reprod. 1992; 7:1342-1346.

26. Johnson J, Canning J, Kaneko T, Pru JK, Tilly JL. Germline stem cells and follicular renewal in the postnatal mammalian ovary. Nature. 2004; 428:145-150.

27. White YA, Woods DC, Takai Y, Ishihara O, Seki H, Tilly JL. Oocyte formation by mitotically active germ cells purified from ovaries of reproductive-age women. Nat Med. 2012; 18:413-421.

28. Bui HT, Van Thuan N, Kwon DN, Choi YJ, Kang MH, Han JW, Kim T, Kim JH. Identification and characterization of putative stem cells in the adult pig ovary. Development. 2014; 141:2235-2244.

29. Fakih MH, Shmoury M, Szeptycki J, Cruz DB, Lux C, Verjee S, Burgess CM, Cohn GM, Casper RF. The AUGMENT SM Treatment: physician reported outcomes of the initial global patient experience. JFIV Reprod Med Genet. 2015; 3:154.

30. Hernandez SF, Vahidi NA, Park S, Weitzel RP, Tisdale J, Rueda BR, Wolff EF. Characterization of extracellular DDX4- or Ddx4-positive ovarian cells. Nat Med. 2015; 21:1114-1116.

31. Zhang H, Panula S, Petropoulos S, Edsgard D, Busayavalasa K, Liu L, Li X, Risal S, Shen Y, Shao J, Liu M, Li S, Zhang D, et al. Adult human and mouse ovaries lack DDX4-expressing functional oogonial stem cells. Nat Med. 2015; 21:1116-1118.

32. Zarate-Garcia L, Lane SI, Merriman JA, Jones KT. FACSsorted putative oogonial stem cells from the ovary are neither DDX4-positive nor germ cells. Sci Rep. 2016; 6:27991.

33. Yuan J, Zhang D, Wang L, Liu M, Mao J, Yin Y, Ye X, Liu N, Han J, Gao Y, Cheng T, Keefe DL, Liu L. No evidence for neo-oogenesis may link to ovarian senescence in adult monkey. Stem Cells. 2013; 31:2538-2550.

34. Zou K, Yuan Z, Yang Z, Luo H, Sun K, Zhou L, Xiang J, Shi L, Yu Q, Zhang Y, Hou R, Wu J. Production of offspring from a germline stem cell line derived from neonatal ovaries. Nat Cell Biol. 2009; 11:631-636.

35. Wu C, Xu B, Li X, Ma W, Zhang P, Chen X, Wu J. Tracing and characterizing the development of transplanted female germline stem cells in vivo. Mol Ther. 2017; 25:1408-1419.

36. Saitou M, Barton SC, Surani MA. A molecular programme for the specification of germ cell fate in mice. Nature. 2002; 418:293-300.

37. Hayashi K, de Sousa Lopes SM, Surani MA. Germ cell specification in mice. Science. 2007; 316:394-396.

38. Nikolic A, Volarevic V, Armstrong L, Lako M, Stojkovic M. Primordial germ cells: current knowledge and perspectives. Stem Cells Int. 2016; 2016:1741072.

39. Castrillon DH, Quade BJ, Wang TY, Quigley C, Crum $\mathrm{CP}$. The human VASA gene is specifically expressed in the germ cell lineage. Proc Natl Acad Sci U S A. 2000; 97:9585-9590.

40. Kee K, Angeles VT, Flores M, Nguyen HN, Reijo Pera RA. Human DAZL, DAZ and BOULE genes modulate primordial germ-cell and haploid gamete formation. Nature. 2009; 462:222-225.

41. Cree LM, Samuels DC, de Sousa Lopes SC, Rajasimha HK, Wonnapinij P, Mann JR, Dahl HH, Chinnery PF. A reduction of mitochondrial DNA molecules during embryogenesis explains the rapid segregation of genotypes. Nat Genet. 2008; 40:249-254. 
42. Wai T, Teoli D, Shoubridge EA. The mitochondrial DNA genetic bottleneck results from replication of a subpopulation of genomes. Nat Genet. 2008; 40:1484-1488.

43. Cao L, Shitara H, Horii T, Nagao Y, Imai H, Abe K, Hara $\mathrm{T}$, Hayashi J, Yonekawa H. The mitochondrial bottleneck occurs without reduction of mtDNA content in female mouse germ cells. Nat Genet. 2007; 39:386-390.

44. Wallace DC, Chalkia D. Mitochondrial DNA genetics and the heteroplasmy conundrum in evolution and disease. Cold Spring Harb Perspect Biol. 2013; 5:a021220.

45. Humpherson PG, Leese HJ, Sturmey RG. Amino acid metabolism of the porcine blastocyst. Theriogenology. 2005; 64:1852-1866.

46. Bode G, Clausing P, Gervais F, Loegsted J, Luft J, Nogues V, Sims J; Steering Group of the RETHINK Project. The utility of the minipig as an animal model in regulatory toxicology. J Pharmacol Toxicol Methods. 2010; 62:196-220

47. Petkov SG, Marks H, Klein T, Garcia RS, Gao $\mathrm{Y}$, Stunnenberg $\mathrm{H}$, Hyttel $\mathrm{P}$. In vitro culture and characterization of putative porcine embryonic germ cells derived from domestic breeds and Yucatan mini pig embryos at Days 20-24 of gestation. Stem Cell Res. 2011; 6:226-237.

48. Woods DC, Tilly JL. Isolation, characterization and propagation of mitotically active germ cells from adult mouse and human ovaries. Nat Protoc. 2013; 8:966-988.

49. Imudia AN, Wang N, Tanaka Y, White YA, Woods DC, Tilly JL. Comparative gene expression profiling of adult mouse ovary-derived oogonial stem cells supports a distinct cellular identity. Fertil Steril. 2013; 100:1451-1458.

50. Xie W, Wang H, Wu J. Similar morphological and molecular signatures shared by female and male germline stem cells. Sci Rep. 2014; 4:5580.

51. Friday AJ, Keiper BD. Positive mRNA translational control in germ cells by initiation factor selectivity. Biomed Res Int. 2015; 2015:327963.

52. Reya T, Morrison SJ, Clarke MF, Weissman IL. Stem cells, cancer, and cancer stem cells. Nature. 2001; 414:105-111.

53. Virant-Klun I, Stahlberg A, Kubista M, Skutella T. MicroRNAs: from female fertility, germ cells, and stem cells to cancer in humans. Stem Cells Int. 2016; 2016:3984937.

54. Cao L, Shitara H, Sugimoto M, Hayashi JI, Abe K, Yonekawa H. New evidence confirms that the mitochondrial bottleneck is generated without reduction of mitochondrial DNA content in early primordial germ cells of mice. PLoS Genet. 2009; 5:e1000756.

55. Cohen J, Scott R, Schimmel T, Levron J, Willadsen S. Birth of infant after transfer of anucleate donor oocyte cytoplasm into recipient eggs. Lancet. 1997; 350:186-187.

56. Ravindranath N, Dalal R, Solomon B, Djakiew D, Dym M. Loss of telomerase activity during male germ cell differentiation. Endocrinology. 1997; 138:4026-4029.
57. Ohinata Y, Payer B, O'Carroll D, Ancelin K, Ono Y, Sano M, Barton SC, Obukhanych T, Nussenzweig M, Tarakhovsky A. Blimp1 is a critical determinant of the germ cell lineage in mice. Nature. 2005; 436:207-213.

58. Fujiwara Y, Komiya T, Kawabata H, Sato M, Fujimoto H, Furusawa M, Noce T. Isolation of a DEAD-family protein gene that encodes a murine homolog of Drosophila vasa and its specific expression in germ cell lineage. Proc Natl Acad Sci U S A. 1994; 91:12258-12262.

59. Telfer EE, Albertini DF. The quest for human ovarian stem cells. Nat Med. 2012; 18:353-354.

60. Byskov AG, Hoyer PE, Yding Andersen C, Kristensen SG, Jespersen A, Mollgard K. No evidence for the presence of oogonia in the human ovary after their final clearance during the first two years of life. Hum Reprod. 2011; 26:2129-2139.

61. Ginis I, Luo Y, Miura T, Thies S, Brandenberger R, GerechtNir S, Amit M, Hoke A, Carpenter MK, Itskovitz-Eldor J, Rao MS. Differences between human and mouse embryonic stem cells. Dev Biol. 2004; 269:360-380.

62. Gook DA, Edgar DH, Borg J, Martic M. Detection of zona pellucida proteins during human folliculogenesis. Hum Reprod. 2008; 23:394-402.

63. Liang L, Soyal SM, Dean J. FIGalpha, a germ cell specific transcription factor involved in the coordinate expression of the zona pellucida genes. Development. 1997; 124:4939-4947.

64. Murakami M, Ichisaka T, Maeda M, Oshiro N, Hara K, Edenhofer F, Kiyama H, Yonezawa K, Yamanaka S. mTOR is essential for growth and proliferation in early mouse embryos and embryonic stem cells. Mol Cell Biol. 2004; 24:6710-6718.

65. Saatcioglu HD, Cuevas I, Castrillon DH. Control of oocyte reawakening by kit. PLoS Genet. 2016; 12:e1006215.

66. Tsai TS, Rajasekar S, St John JC. The relationship between mitochondrial DNA haplotype and the reproductive capacity of domestic pigs (Sus scrofa domesticus). BMC Genet. 2016; 17:67.

67. Jansen RP, de K. The bottleneck: mitochondrial imperatives in oogenesis and ovarian follicular fate. Mol Cell Endocrinol. 1998; 145:81-88.

68. Ye K, Lu J, Ma F, Keinan A, Gu Z. Extensive pathogenicity of mitochondrial heteroplasmy in healthy human individuals. Proc Natl Acad Sci U S A. 2014; 111:10654-10659.

69. Samuels DC, Li C, Li B, Song Z, Torstenson E, Boyd Clay H, Rokas A, Thornton-Wells TA, Moore JH, Hughes TM, Hoffman RD, Haines JL, Murdock DG, et al. Recurrent tissue-specific mtDNA mutations are common in humans. PLoS Genet. 2013; 9:e1003929.

70. Elliott HR, Samuels DC, Eden JA, Relton CL, Chinnery PF. Pathogenic mitochondrial DNA mutations are common in the general population. Am J Hum Genet. 2008; $83: 254-260$. 
71. Johnston IG, Burgstaller JP, Havlicek V, Kolbe T, Rulicke T, Brem G, Poulton J, Jones NS. Stochastic modelling, Bayesian inference, and new in vivo measurements elucidate the debated mtDNA bottleneck mechanism. Elife. 2015; 4:e07464.

72. Otten AB, Stassen AP, Adriaens M, Gerards M, Dohmen RG, Timmer AJ, Vanherle SJ, Kamps R, Boesten IB, Vanoevelen JM, Muller M, Smeets HJ. Replication errors made during oogenesis lead to detectable de novo mtDNA mutations in zebrafish oocytes with a low mtDNA copy number. Genetics. 2016; 204:1423-1431.

73. Sharpley MS, Marciniak C, Eckel-Mahan K, McManus M, Crimi M, Waymire K, Lin CS, Masubuchi S, Friend N, Koike M, Chalkia D, MacGregor G, Sassone-Corsi P, Wallace DC. Heteroplasmy of mouse mtDNA is genetically unstable and results in altered behavior and cognition. Cell. 2012; 151:333-343.

74. Ross JM, Stewart JB, Hagström E, Brené S, Mourier A, Coppotelli G, Freyer C, Lagouge M, Hoffer BJ, Olson L, Larsson NG. Germline mitochondrial DNA mutations aggravate ageing and can impair brain development. Nature. 2013; 501:412-415.
75. Barritt JA, Cohen J, Brenner CA. Mitochondrial DNA point mutation in human oocytes is associated with maternal age. Reprod Biomed Online. 2000; 1:96-100.

76. Seifer DB, DeJesus V, Hubbard K. Mitochondrial deletions in luteinized granulosa cells as a function of age in women undergoing in vitro fertilization. Fertil Steril. 2002; 78:1046-1048.

77. Neupane J, Ghimire S, Vandewoestyne M, Lu Y, Gerris J, Van Coster R, Deroo T, Deforce D, Vansteelandt S, De Sutter P, Heindryckx B. Cellular heterogeneity in the level of mtDNA heteroplasmy in mouse embryonic stem cells. Cell Rep. 2015; 13:1304-1309.

78. Facucho-Oliveira JM, St John JC. The relationship between pluripotency and mitochondrial DNA proliferation during early embryo development and embryonic stem cell differentiation. Stem Cell Rev. 2009; 5:140-158.

79. Mi H, Muruganujan A, Casagrande JT, Thomas PD. Large-scale gene function analysis with the PANTHER classification system. Nat Protoc. 2013; 8:1551-1566. 